\title{
The landscape of fear conceptual framework: definition and review of current applications and misuses
}

\author{
Sonny S Bleicher Corresp. 1, 2 \\ 1 Ecology and Evolutionary Biology, University of Arizona, Tucson, Arizona, United States \\ 2 Tumamoc People and Habitat, Tuamamoc Desert Research Laboratory, University of Arizona, United States \\ Corresponding Author: Sonny S Bleicher \\ Email address: bleicher.s.s@gmail.com
}

Landscapes of Fear (LOF), the spatially explicit distribution of perceived predation risk as seen by a population, is increasingly cited in ecological literature and has become a frequently used "buzz-word". With the increase in popularity, it became necessary to clarify the definition for the term, suggest boundaries and propose a common framework for its use. The LOF, as a progeny of the "ecology of fear" conceptual framework, defines fear as the strategic manifest of the cost-benefit analysis of food and safety tradeoffs. In addition to direct predation risk, the LOF is affected by individuals' energetic-state, interand intra-specific competition and is constrained by the evolutionary history of each species. Herein, based on current applications of the LOF conceptual framework, I suggest the future research in this framework will be directed towards: (1) finding applied management uses as a trait defining a population's habitat-use and habitat-suitability; (2) studying multi-dimensional distribution of risk-assessment through time and space; (3) studying variability between individuals within a population; and (4) measuring econeurological implications of risk as a feature of environmental heterogeneity. 
1 The landscape of fear conceptual framework: definition and review of current 2 applications and misuses

3 Sonny S. Bleicher ${ }^{1,2}$

4 1. Ecology and Evolutionary Biology, University of Arizona, Tucson, AZ, USA

5 2. Tumamoc People and Habitat, University of Arizona, Tucson, AZ, USA

6 Corresponding author's email: bleicher.s.s@gmail.com 


\section{Abstract}

8

Landscapes of Fear (LOF), the spatially explicit distribution of perceived predation risk

9 as seen by a population, is increasingly cited in ecological literature and has become a frequently

10 used "buzz-word". With the increase in popularity, it became necessary to clarify the definition

11 for the term, suggest boundaries and propose a common framework for its use. The LOF, as a

12 progeny of the "ecology of fear" conceptual framework, defines fear as the strategic manifest of

13 the cost-benefit analysis of food and safety tradeoffs. In addition to direct predation risk, the

14 LOF is affected by individuals' energetic-state, inter- and intra-specific competition and is

15 constrained by the evolutionary history of each species. Herein, based on current applications of

16 the LOF conceptual framework, I suggest the future research in this framework will be directed

17 towards: (1) finding applied management uses as a trait defining a population's habitat-use and

18 habitat-suitability; (2) studying multi-dimensional distribution of risk-assessment through time

19 and space; (3) studying variability between individuals within a population; and (4) measuring

20 eco-neurological implications of risk as a feature of environmental heterogeneity. 


\section{Introduction}

The study of community ecology has developed from a study of how species affect each other in terms of resource competition to the study of how that competition affected community structure over evolutionary time (Morris \& Lundberg, 2011). In other words, how species' resource-use efficiency impacts inter-species interactions on an evolutionary scale — resulting in present day community structures shaped by extinction and speciation events (Vincent \& Brown, 2005). This historical shift can be traced back to the model that first tested top-down trophic cascades (e.g. Paine, 1963), and large collaborative and conceptual efforts to explain the dynamics driven by predator-prey interactions (e.g. Hassell, 1978; Murdoch \& Oaten, 1975; Rosenzweig \& MacArthur, 1963). These efforts continue today, and predominantly focus on the study of non-consumptive effects of predators on entire communities (Appendix I)(e.g. Kotler, 1984; Sih et al. 1998). Joel Brown colloquially referred to these non-consumptive effects as the “ecology of fear" (Brown, Laundrè \& Gurung, 1999).

While the ecology of fear continued to focus on the means by which community structure impacts specific behaviors, some choose to broaden the study to the ecosystem level (e.g. Madin, Madin \& Booth, 2011). Such theses assess ecosystem health using the trophic cascades as the basis for a new theory of behavioral cascades reverberating down the food chain and affecting habitat selection of species along the chain.

John Laundré (2001) called the effect, behavioral-pattern, resulting from these trophic cascades the "Landscape of Fear" (LOF). The use of the LOF, as a concept, is gaining favor as more studies investigate spatial dynamics in the distribution of populations using a community centric lens. This review has two main objectives: (1) clearly define the LOF, while dispelling common misuses of the term. And (2) discuss how the current literature uses LOFs, suggesting 
45 future trajectories possible for this growing research program.

\section{Review Method}

47 For the purpose of this review, I conducted a literature search for manuscripts that use the

48 term "landscape(s) of fear" as part of their title, or within their key-words and abstracts. The

49 search was conducted on Google Scholar@, Wiley Interscience Online Library@, JSTOR@ and

50 Thompson Reuters' Web of Science C. Every manuscript found in the search was examined and

51 if it studied spatial distribution of predation risk it was included in the database. Every

52 manuscript was mined for the following information: definition of the LOF(s), article type

53 (review, opinion, or empirical), publication aim (based on journal guidelines), method used and

54 study system (in studies providing data), and the theoretical contributions each brings to the field

55 (if any). Three manuscripts were added to the database (despite not mentioning LOF per-se in

56 their abstracts, or being peer reviewed): my own Ph.D. thesis (Bleicher 2014) and two

57 manuscripts that were cited regularly in other manuscripts (Zanette \& Jenkins, 2000; Ripple \&

58 Beschta, 2003).

\section{Defining the LOF}

Among growing interpretation of the LOF concept it is critically important to provide a concise and clear definition. The LOF is a behavioral trait of an individual animal, and more commonly used on the population level. The LOF provides a spatially dependent, yet geographically independent, measure of the way an animal "sees" it's world—it's umwelt (cf. Uexküll, 1909). In other words, it is a short term measure of the way the animal perceives its environment based on the cost-benefit analysis of the tradeoff of food and safety associated with foraging in specific areas of the habitat available to it (cf. Brown, Laundré \& Gurung, 1999). As 
67 such, LOFs are affected by a large variety of biological, evolutionary and yes- sometimes

68 geographic variables.

69 (1) Predation risk.

70 The most studied factor impacting an animal's LOF is direct and perceived predation risk

71 (cf. Laundré, Hernández \& Altendorf, 2001; Laundré, Hernandez \& Ripple, 2010). Within

72 predation risk, three major factors impact the LOF: (1) diversity of the predator community, (2)

73 predation intensity [activity of predators] and (3) information [how well can the animal predict

74 the likelihood of being attacked] (Brown, 1999).

A forager has to strategically decide where to forage based on the type of risk presented

by the predators it is likely to face. For example, the decisions a forager must take to manage risk

77 from ambush predators will differ greatly from those it will take to manage risk from a flying

predator. In a case of Negev Desert gerbils facing barn owls and vipers, gerbils showed an ability

to alter their LOF to adjust to the owl, a larger perceived threat than vipers, during the nights an owl is present in the experimental vivarium (Bleicher, 2014). Similarly, the features of the LOF will change based on the predator activity levels. A number of studies use landscape rugosity, how "wrinkled" the landscape appears, as a means to express heterogeneity in patterns of perceived-risk distribution (Laundré et al., 2010, Bleicher, 2014). The best variable proposed to measure this feature of the LOF is the mean rate of change in foraging tenacity over space (mean harvested resources/meter). The greater the risk, the steeper the difference between safe and risky zones in the LOF. Thus, mean rugosity should increase as predator activity levels increase

87 (Brown \& Kotler, 2004). 
90 landscapes (using energetic-expenditure to explain movement through space) should be

91 combined as they are two facets of the same coin. In many ways, they are correct, however the

92 field of LOF has already focused a large portion of its scientific effort to quantifying the LOF

93 using energetic tradeoffs, and foraging in particular.

This was first justified using an example with cape ground squirrels (Xerus inauris) where

the costs associated with the distance they must venture from shelter altered their perception of risk (Van Der Merwe \& Brown, 2008). Distance from refuge was an exercise in adding nondirect predation costs into the calculation of the LOF. This is important since over short periods, and small spatial scales, metabolic costs and missed opportunity costs are constant across the landscape. Examining these costs thus allows the extrapolation of the LOF from the temporally and spatially much more sensitive predation cost of foraging.

The possible variables that could alter an animal's LOF include both physiological and external variables. Individuals (and populations) should take greater risk based on the increase in stress imposed by drought, blight, disease and parasites. Assuming optimal foraging, perceived resource availability should affect forager decisions. Stressed foragers will likely visit patches of greater risk-variability (high likelihood of a patch not yielding resources) (Real \& Caraco, 1986). Alternately, resource shortage, will drive the stressed foragers to take risks by moving greater distances in search of isolated high quality patches, as in the case of Simpson Desert dunnarts (Haythornthwaite \& Dickman, 2006; Bleicher \& Dickman, 2016). Another factor impacting the energetic balance of the LOF is parasite load, both physiologically and behaviorally (Raveh et al., 2011). behavior, namely water shortage (e.g. Shrader et al., 2008; Tadesse \& Kotler, 2011; Arias-Del 
113 Razo et al., 2012). In times of drought, thirsty herds of African savannah ungulates are known to

114 descend to water holes teeming with crocodiles and other predators. In this case the probability

115 of escaping the predators, though meager, is still lower than the probability of dying from

116 dehydration. It is the balance of risk and energetics that governs the LOF choices in the majority

117 of cases.

118 (3) Demographics

119 The success of an individual, its fitness, is measured not by the amount of energy (food)

120 it successfully harvests from the environment, but in the successful conversion of that energy

121 into viable offspring. Thus, competition for mates and care for offspring have an important role

122 in determining both resource needs and risk-taking probability in opposite direction. Because of

123 the time sensitivity of both offspring care and mating seasons, these shifts in behaviors will

124 temporarily change the LOF for each individual, and collectively for the population.

In a study of collared peccaries, mothers protecting offspring remained in the safety of a

126 wadi while males, not concerned with offspring safety, were observed foraging on resources near

127 a hiking trail frequented by 1500 visitors daily (Bleicher \& Rosenzweig, in preparation). This

128 phenomenon, of parental intimidation, and it's deleterious reproductive consequence were

129 observed in a study on song sparrows (Zanette et al., 2011). On the flip side, during courtship,

130 risk-taking in males, as in examples of lek behaviors, can lead to increased reproductive success

131 (Boyko et al., 2004).

132 (4) Density Dependence- Intraspecific Competition

133 Living in a group provides safety in numbers (Rosenzweig, Abramsky \& Subach, 1997),

134 however the intraspecific competition can result in deleterious impacts on the foraging efficiency

135 of individuals affecting the entire population's fitness (Berger-Tal et al., 2015). Spatially, 
136 ecologists assume ideal free distribution, suggesting that the populations will disperse when the

137 environmental conditions do not meet ideal fitness returns for individuals (Morris, 2003). By

138 changing the spatial resolution on which we make our observations, we undoubtedly will be

139 exposed to different stories. On fine-grained resolution we can observe the decision-making

140 process impacting individual, however on a larger, course-grained resolution we are generally

141 privy to the dynamics of the entire population (Druce et al., 2009). No empirical manuscript has

142 yet to test the effects of density dependence on the landscape of fear as they materialize for

143 populations of different sizes. It is likely that this specific factor will become the focus of more

144 studies in the future.

145

146

147

148

149

150

151

152

153

154

155

156

157

158

\section{(5) Community structure - Interspecific Competition}

The study of habitat selection has been largely dominated by community studies testing strong-weak competitor pairs of species (e.g. Rosenzweig, 1973; Dickman, 1986; Abramsky, Rosenzweig \& Subach, 2001; McGill et al., 2006). Most of these studies suggest that a strong, more aggressive competitors, forces the weak to forage in less profitable habitat (greater risk/ lower resources). This can also manifest itself in temporal partitioning (Kotler et al., 2002). This evidence strongly suggests that the LOF of a population in isolation will not compare with the same population's LOF when competing for resources.

A couple of studies thus far have identified (or referred to) the impacts of competition on the LOF of competing species. (1) Competition for resources had greater impact on habitat selection in lemmings. This was attributed to the fact that the foraging season is very short and risk aversion may lead to starvation over the arctic winter (Dupuch, Morris \& Halliday, 2013). In another example, the competition for resources can manipulate the distribution of predators. (2) 
159 In studies at various sites in Australia, dingo presence suppressed mesopredator populations 160 (Ritchie \& Johnson, 2009). Similarly, the competition between the invasive mesopredators 161 suppresses the population of the competitor. When foxes are hunted, the feral cat populations 162 explode and vice versa (Glen \& Dickman, 2005; Allen, Allen \& Leung, 2015), this in turn has a 163 trickle-down effect on prey species’ LOFs.

164 (6) Evolutionary History - Ghosts of Predator and Competitor Past.

165 Behavioral and applied ecologists rarely study the evolutionary history of their species. The 166 conditions (environment, community structure, resources) in which the species evolved will 167 determine the tools which the species has to assess risk. In turn, these tools are applied by 168 individuals to make the strategic decisions that manifest themselves in their LOFs. Comparing populations that use different habitat, or convergent species from similar environment may provide insight to the role of a larger meta-scale, both temporal (evolutionary and seasonal) and geographic (continents), in determining each population's LOF.

172 The only example I found for such a study, was a macroevolutionary study where populations of convergent desert rodents were brought to a common arena and exposed to

174 predator present in both systems, vipers and barn owls (Bleicher, 2014). Rodents of the Mojave 175 Desert, that evolved with vipers that have heat sensing capabilities focused on the snakes as the 176 focal driver of their LOF. The owl presence only elevated the risk in the entire landscape.

177 Rodents of the Negev Desert, who evolved with snakes blind in the dark, fear owls above 178 snakes (Kotler et al., 2016). As a result, they redraw their LOF based on the greatest risk in the 179 environment. On nights with vipers alone, they identify the ambush sites of snakes and avoid 180 those. On nights with both vipers and owls they avoid the flight paths of the owls in the arena 181 (vivarium). 
182 Misinterpretation - avoiding misuse

183 There are three major misuses commonly published in the LOF literature. It is important to

184 state them and discuss how these could be easily avoided for the benefit of this research

185 program.

(1) Using the LOF concept interchangeably with habitat use. Animals will avoid habitat they perceive as risky, therefore the LOF plays a critical role in habitat use and habitat selection. However,

it is important to re-emphasize that it is the habitat quality that is responsible in shaping the LOF.

Thus, using the LOF to explain habitat use needs to be approached with caution. While activity data can reveal habitat use, they do not necessarily reveal the LOF. As an example, a rich food source can attract foragers and enhance activity to a given area without reduced risk necessarily being involved. This confusion is perpetuated by the fact the $81 \%(63)$ of manuscripts apply the LOF as a descriptor for habitat-selection. This problem is exacerbated by the fact the majority of manuscripts that misinterpret the term are able to draw sound conclusions about habitat selection (e.g. Creel et al.,2005; Madin, Madin \& Booth, 2011). I suggest here, that when using the LOF as a descriptor for habitat-selection, one should also cross reference other critical factors, such as availability of food, shelter (nest sites, borrows, cavities), water etc.

(2) Suggesting predators impose a LOF. It is very metaphorically colorful to suggest that the presence of a predator imposes a LOF (e.g. Lone et al., 2014; Massey, Cubaynes \& Coulson, 2013), however, every population interprets risk cues even in the absence of predators. This misinterpretation is most commonly published in applied journals, with 47\% (9) of the appliedecology manuscripts making this type of statement. The appropriate expression of these ideas, must refer to changes in the perceived risk associated with features in the landscape. This distinction was best shown in a study of vervet monkeys responding to playback of alarm calls 
205

206

207

208

209

210

211

212

213

214

215

216

217

218

219

220

221

222

223

224

225

226

corresponding to different predator types. This experiment generated three dimensional LOFs based on elevation in trees and spatial-distribution of safe zones within the troop's home-range (Willems and Hill, 2009). Each call-type changed the monkeys' preferred habitat.

(3) Using the LOF as jargon without defining the term. Though not common, 4\% (3) of the manuscripts used the term, LOF, without defining it.

\section{General Review Results}

Since the year 2000, 77 manuscripts (Appendix II) were published either using the term LOF (in title, key-words or abstract). The publication rate has been increasing steadily since 2001, with a mean of 5.1 $\pm 0.7 \mathrm{SE}$ manuscripts per year (Figure 1).

Of these 77 manuscripts $75 \%$ are empirical tests that employ the concept, while the rest of the manuscripts discuss implications in form of review and opinion papers. The majority of papers $(76 \%)$ were published in journals dedicated to general ecology and zoology (e.g. Ecology (C), Oikos (C) and the Canadian Journal of Zoology (C) (Table 1).

With the rise in popularity of the term, the rate of misuse has also increased significantly. Between 2001-2009 a mean of 11\% of the publications (per annum) used a definition different than the one intended by Laundré and Brown based in the "ecology of fear" (Brown, Laundré \& Gurung, 1999). Between 2009-2016 the rate of misuse of the term increased to a mean of 35\%.

(Figure 1). For the purpose of the discussion ensuing, I categorized manuscripts that use a definition other than "a variation on a behavioral descriptor of the perception of risk a population sense in the environment" as "buzzword" papers. A number of manuscripts used the LOF to describe features of the environment as belonging to an animal's LOF or define LOFs as traits of an individual (Table 1). If the manuscripts referred to the LOF as an intrinsic perception of the 
227 way an organism balances risk and energetic gains they were classified as relevant (Table 1).

$228 \quad 38 \%(31)$ of the manuscripts discuss theoretical implications of LOFs. Of these, about half

229 make suggestions that are of particular mention (Table 2). These contributions included ways to

230 describe LOFs' features, novel applications for which the LOF framework, novel methods to

231 measure the LOF, or discussions on the merit of LOF as a research group (see applications

232 section).

233 Measuring the LOF.

234 From this point in the manuscript I will only refer to a subset of the manuscripts that used

235 my definition of a LOF (57 in total). The majority of these manuscripts focused on ungulates in

236 North American alpine scrubland systems (Table 3A,B). It was the wolf-elk-willow system that

237 brought the LOF into common ecological jargon through the study of successful reintroduction

238 of wolves to Yellowstone National Park. Despite the base of the LOF in ungulate research, many

239 studies preferred the variability provided by small-mammal model species (gerbils, heteromyids,

240 lemmings and voles). Researchers have manipulation capabilities in small mammals resulting in

$24140 \%$ (6) of these studies being performed in controlled captive environments (vivaria). These

242 vivaria allow for the manipulation of predation risk and environmental conditions: e.g.

243 homogenous landscapes, illumination, resource availability, energetic state of the population etc.

244 The rise in small-mammal experiments also secured the giving-up density (GUD; $c f$. Brown,

245 1988) as the preferred measure of LOFs (Table 3B).

Given species-specific constraints, each class of organisms has a specialized-tool kit used

247 to measure its LOF (Table 3B). GUDs remain the most versatile measure for the studies using

248 habitat assessment (59\% of the manuscripts) and historically were successfully used to measure

249 environmental stress in birds, ungulates, small mammals and experimentally_fish (Bedoya- 
250 Perez et al., 2013). Larger mammals and finicky foragers pose challenge to the GUD method. As

251 a result, the LOFs for larger species were commonly measured applying occupancy models using

252 variables such as scat abundance, hoof mark density and trail camera arrays (19\% of

253 manuscripts). Measuring predator (and marine) LOF provides even further challenge due to low

254 density of populations. Thus, the major tool used was radio and GPS tracking. Despite being a

255 very small proportion of the current literature base, some efforts have been made to quantify

256 environmental risk using stress hormones. So far, this method has been limited to birds

257 (Chalfoun \& Martin, 2009; Roper, Sullivan \& Ricklefs, 2010; Clinchy et al., 2011).

Thus far, 38\% (17) manuscripts provided a map for the study organism's LOF. These maps help readers relate with associated distribution of risk the studied population experiences. The majority of these have used the GUD as the measure of risk and graphed the LOF map as a three dimensional scatter plot, using a distance-weighted-least-squares (DWLS) smoothing function to generate the contour lines (or raster) for the maps (Figure 2).

The current literature linguistically borrows attributes from other ecological, evolutionary and geographic theories to describe the zones of different risk characteristics. For example, in a study of striped mice, the features of risky habitat was described as "islands" of fear, a reference to the island-biogeography theory and the SLOSS debate ( $c f$. Diamond, 1975). This study mice perceive in the environment (Abu Baker \& Brown, 2010).

In a previous review, Laundré et al. (2010) prefer to describe the landscape features as valleys and peaks (re: safe to risky) in an aim to show that risk assessment is a quantitative attribute and not a binomial characteristic (two distinct outcomes risk or safety). Lastly, my own

272 work evaluated the role played by gradients of change (in perceived risk) describe the attributes 
273 of the decision making process made within the LOFs.

274 This measure can be described as the rugosity of the landscape (Bleicher, Kotler \& Brown,

275 2012; Bleicher, 2014). A highly rugose landscape (highly variable with steep changes between

276 points) implies that the population perceives the risk as localized. In comparison, flat landscapes

277 can be interpreted as the result of one of two distinct behavioral strategies. (1) A flat LOF may

278 be the result of a very "fearful" population whereas the majority of the environment "plateaus"

279 on a high risk contour. In such a LOF, the major focus of the behavior remains in contact with

280 the locations of refuge in the landscape and the risk lessens gradually as one moves near the

281 refuge. Alternately, (2) a population that is "secure" in its management ability of predation risk

282 from the predators in the environment will have a very flat (low) landscape. In this scenario, the

283 zones of risk are less focused and tangible and thus the change between "riskier" and "safer"

284 zones is gradual and not very distinct.

\section{Current Applications}

286 Of the manuscripts defining a LOF as a trait of population behavior, 42 were empirical.

287 Within those it is possible to divide the aims of the manuscripts into four focal aims: (1) to

288 characterize the role of perceived predation risk on habitat use by wild and captive populations,

289 (2) to project top-down trophic effects, (3) to understand how habitat complexity affects

290 demographic and behavioral dynamics within populations and (4) deconstruct community

291 interactions within an evolutionary framework.

\section{2 (1) Population level}

293 The majority, 76\% (33), of empirical manuscripts using the LOF, and almost all, 92\%, of the 294 manuscripts that provided visual charts of the LOF, aimed to study how populations perceive 
295 their environment. Thus, the majority of publications apply the LOF as an equivalent to habitat

296 selection. As mentioned above, this has given rise to a large misinterpretation of the LOF. The

297 large number of publications here makes the review of these largely unnecessary. However, there

298 are a couple of noteworthy examples that did impact the understanding of the LOF.

Druce et al. (2009) showed in his study of klipspringers that the study-scale can reveal 300 different patterns of elements impacting a LOF. In this study, the small scale (grids of stations 34 meters apart) showed that microhabitat (cover, distance from rocky outcrops) impacted forgiving decisions specifically on a temporal scale. But on larger scales (grids of 6-24 stations 30 meters apart), the major geographic features of the landscape (substrate, drainage lines) explained the majority of variation in foraging decisions. This study drew the attention to the importance of natural history to calibrate experiments to study the focal population on terms relevant to their specific ecology. distribution of wolf kill-sites than habitat suitability for hunting. This study made two noteworthy contributions to the understanding of fear-based habitat use. (1) Predators are constrained in their activity by elements beyond prey availability and ease of hunting. (2) Information about predator limiting factors, gained through experience cohabitating with the predators, will alter prey decision-making. In this case, given enough information, prey will likely prefer habitat of territorial dispute between wolf-packs.

315 Despite the fact that the origin of the LOF framework is in trophic cascades, only half (22 total and 13 empirical) of the manuscripts actually include multi-trophic studies (Table 4).

317 Noteworthy examples of multi-level studies include the trickle down of shark predators on algal 
318 blooms in tropical reefs (Madin, Madin \& Booth, 2011). Additionally, Manning, Gordon \&

319 Ripple (2009) offer a predictive study of the impact reintroducing wolves to Scotland would

320 have on vegetation patterns. This study drew direct parallels to vegetation regeneration post the

321 reintroduction of wolves into Yellowstone National Park (Beschta \& Ripple, 2009; Ripple \&

322 Beschta, 2012).

323 The majority of the studies that did use a trophic framework, only looked at a pair of species

324 (predator-prey) (Table 4). Interesting examples of these include the study of predator facilitation

325 and interference (e.g. Ritchie \& Johnson, 2009; Embar et al., 2014). Similarly, there is a fair

326 number of studies that question the role of predation risk in the distribution of the prey

327 populations. Two good studies can be shown for this category. (1) Coyote distribution (scat) does

328 not correlate with the distribution of jackrabbits and other desert rodents in Chihuahuan high

329 desert (Laundré, Calderas \& Hernández, 2009). And (2) sharks and sea turtles do not show the

330 same pattern of spatial and temporal rates of surfacing behavior (Hammerschlag et al., 2015).

331

332

333

334

335

336

337

338

339

(3) Individual-based LOFs.

This category of applications represents a very small proportion (5\%) of the manuscripts, however that subset is of utmost importance in developing the study of LOFs. Those manuscripts define the LOF as a population trait, however they acknowledge individual variation within the population. Each of the three studies took a very different approach. within fragmented forest segments. They suggest that the more fragmented the habitat, the more stressed the parenting birds are, and thus the offspring are less likely to fledge. On the flipside, this suggests that parental stress becomes a predictor of predation risk, or predator distribution. 
Rypstra et al. (2007) found that wolf-spiders exposed to a larger predatory spider were driven into a mixed habitat where their prey capture rate was significantly diminished. Individuals who were not exposed to the larger spiders were found in exposed, i.e. risky, habitat and were found

343 to have a greater hunting success. This study suggests that gaining information about predator 344 preferences (through cues) causes a shift in an individual's LOF. This approach provides insight 345 into the learning process, or loss of naiveté, that is hard to observe in natural settings. et al., 2007). This study found that turtles with low fat reserves were likely to forage in shark infested waters, while healthier individuals remained in shallow waters and low shark habitat. This study shows that individual well-being affects the way that individual perceives the tradeoff of food and safety. As a result if the LOF was measured for groups of turtles based on their energetic state, a different shape would be revealed. and individuals. This suggests that the forces historically influencing the study of populations' ancestors, ghosts of predator and competitor past, would mold the way they present day descendants respond to the tradeoffs of food and safety. that lemmings that evolved in arctic conditions, with limited time to store resources for the long winters, give precedence to competition over the risk of predation (Dupuch, Morris \& Halliday, 2013). This study, provided the incentive to use the LOF to ask questions comparing species within the same trophic level. It provided the framework to measure competitor strategies using 
363 spatial distribution of risk perception. This study inspired the four way comparison (captive

364 study) of convergent rodents from two continents under the predation risk of predators shared by

365 both systems (Bleicher, 2014).

366 In this study, two heteromyid rodents, from the Mojave Desert, and two gerbil species, from

367 the Negev Desert, were exposed to treatments of vipers and owls in a homogeneous semi-natural

368 arena. The heteromyids that evolved alongside vipers that use heat-sensing pits to "see" in the

369 dark, exhibited fixed LOFs that did not change their shape when owls were added to the vipers

370 constantly present in the environment. Meanwhile the middle-eastern gerbils, who evolved with

371 snakes "blind" in the dark, exhibited plastic LOFs. They altered their LOF, adjusting the

372 topography in ways that address risk that is derived from unique adaptations to manage risk from

373 different types of predators. In other words, focusing the peaks and valleys on the activity

374 pattern exhibited by the predator they perceived as the greatest risk. For these gerbils, this meant

375 the owl (Kotler et al., 2016). In its absence the LOF peaks were centered around viper ambush 376 sites.

\section{Prospectus - Developing the LOF for future applications.}

378 I would like to "throw the gauntlet" to my colleagues and offer the following five

379 directions in which the LOF concept can be applied.

380 (1) Conservation and applied management

381 Despite the theoretical background of the LOF in conservation efforts and the reintroduction

382 of wolves to Yellowstone National Park, the active management of populations has not measured

383 LOFs as a monitoring tool. Charting the LOF can provide a temporal snapshot of the way

384 populations see their environment. With relatively low effort (installing a food patch matrix), and 
385 in a short time-frame (4-15 repetitions), one can, for example, ascertain the efficiency of a

386 habitat augmentation program ( $c f$. Bleicher \& Dickman, in preparation). Similarly, the LOF can

387 provide an accurate measure of the impact of human activity has on species of conservation

388 concern without waiting for demographic changes in the population. Additionally, one could use

389 the LOF to physically study how we can increase the perception of risk a pest population senses

390 in an area (cf. Bleicher and Rosenzweig, in preparation). By cues of predation risk (sound, odor)

391 as management treatments (e.g. Suraci et al., 2016), one could follow the changes in spatial

392 distribution of the pests. Such methods could be applied, for example, in air-fields to lower

393 wildlife-impacts and control agricultural pests.

\section{4 (2) The LOF studied on meta-scales}

395

396

397

398

399

400

401

402

403

404

405

406

407

The macro-evolutionary perspective - comparing the populations, species and communities that evolved under different conditions - requires comparisons on very large geographic scales as well as cross-species comparison. To achieve such comparisons studies have two possible designs: (a) run common-garden experiments bringing populations with varying evolutionary background to a shared location (e.g. Bleicher, 2014; Kotler et al., 2016; Bleicher, Kotler \& Brown, in preparation) or (b) run comparative studies within areas of similar habitat at geographically isolated locations. Such studies have the ability to shed light on how predator-prey dynamics of the past drive current-day mechanisms of species coexistence.

Above, I suggested that the environmental conditions at the time data is collected to generate the LOF, impacts the shape of the LOF. As LOFs provide a short-term "picture" of how populations perceive their environment, field-studies will require repeated measures to understand how risk perception is affected by drought, population booms or busts, predator density or activity. Similarly repeated measures along an extended period of time would be 
408 required to monitor habitat restoration or augmentation. For example, a study that used the LOF

409 to look at the effectiveness of shelter augmentation (Bleicher and Dickman, in preparation)

410 suggested that the study must be repeated once the populations recovered from the bust induced

411 by bush-fires and a prolonged drought. As in this example, the shape of the LOF should alter

412 based on the increased inter- and intra-specific competition and by the additional resources and

413 shelter that successional vegetation will provide. Despite this well-known (and discussed)

414 temporal constraint, no studies have yet to follow-up with repeated measures. The exception to

415 this is the follow-up on the Yellowstone wolf reintroduction that looked predominantly at plant

416 diversity and abundance of aspens and willows but did not measure the elk or bison's LOF

417 (Ripple and Beschta, 2012).

418 (3) The 4D LOF.

419 Mapping the LOF provides a level of intricacy that categorical analysis can fall short of

420 explaining. The growing number of studies offering contour maps (3D scatterplots) of the LOF is

421 a sign for the increasing prominence of spatial statistics in current ecology. Studies in primates

422 and brushtailed possums suggest that elevation has as much significance as landscape

423 heterogeneity in the management of risk from a variety of predators (Willems and Hill, 2009;

424 Emerson, Brown \& Linden, 2011; Mella, Banks \& Mcarthur, 2014). Similar to those mammals,

425 most species do not live on a two dimensional plane. Therefore, one must conclude that the

426 future of the field will aim towards 4D and 5D models that incorporate altitude (aerial, aquatic

427 or above/ below ground) and time (hourly, seasonal, annual or generational).

428 (4) The personality-based individual LOF

429 Populations are comprised of individuals with differing phenotypic expressions on an axis

430 limited by the niche breadth (range of possible expression forms) of each trait (Vincent \& 
431 Brown, 2005). When we measure variability on the population level we average out the "noise"

432 produced by the variation in individual response. The focus on the individual is gaining

433 prominence in behavioral ecology. Specifically the study of bold-shy expression and how they

434 affect risk assessment (e.g. Ioannou, Payne \& Krause, 2008) and the spread of invasive species

435 (e.g. Fogarty, Cote \& Sih, 2011) as a couple of examples.

436 Variability of traits within a population is a pillar of Darwinistic evolution, and I suggest that

437 the LOF may provide a platform to study consequences of changing behavioral traits.

438 Manipulative experiments could subject stressors on a selective group within a population,

439 following how these treatments change the individual's risk assessment from the overall

440 population. Some of these manipulative studies already exist, however they did not focus on the

441 spatial components of the behavioral response. An example of such a study is the effect of

442 parasites and the distraction they produce on the risk-taking behavior in gerbils (e.g. Raveh et al., 443 2011).

444 Some manipulative studies of this sort could involve: group size and density dependence 445 (does group size influence the boldness of individuals?); Energetic-state (does the hungry 446 individual take greater risks than satiated individuals in a group?), demographics (does a male 447 take more risk when competing for mates with many other males?, or do females with offspring 448 reduce the risk-taking in comparison with the males in the group?) and more.

449 (5) The neurology of LOFs.

450 The last frontier to the LOF studies I wish to highlight is the neuro-ecology of fear. i.e.

451 converting environmental risk into a measureable impact on stress syndromes. When an animal

452 is under stress (risk of predation specifically), the neurological registering of the risk cues causes

453 an increase in stress hormones being released in the body of the animal (Gross \& Canteras, 
454 2012). The physiological responses to these stress hormones are energetically costly (Apfelbach

455 et al., 2005) and result in lowered productivity (e.g. Mukherjee et al. 2014).

456 For example, sparrows are shown to respond with an increase of a variety of stress hormones

457 (plasma total corticosterone, corticosteroid binding globulin (CBG) and free corticosterone) in

458 response to an increase in the risk of predation in the environment (Zanette et al., 2011). Creel et

459 al. (2013) suggest that competition may play a similar role in producing stress hormones, and

460 should result in changes in population dynamics. I agree with Clinchy et al. (2013) in suggesting

461 that this connection of environmental stress and neurological responses is a fertile ground for

462 research. It is important to move away from the chronic stress studied in laboratory animals into

463 spatially explicit studies within realistic ecological scenarios.

\section{Acknowledgments}

465 I would like to thank B.P. Kotler, J.S. Brown, C.R. Dickman, J.W. Laundré and M.L.

Rosenzweig for conversation and guidance that inspired this research. I would like to extend a

special thanks to A. Halloway, J. Bernhart, A. Adivrekar and D. \& L. Bleicher for editorial comments both in contents and in copyediting.

469

470

471

472

473

474

475

\section{References:}

Abramsky Z., Rosenzweig ML., Subach A. 2001. The cost of interspecific competition in two gerbil species. Journal of Animal Ecology 70:561-567.

Abu Baker MA., Brown JS. 2010. Islands of fear: effects of wooded patches on habitat suitability of the striped mouse in a South African grassland. Functional Ecology 24:13131322. DOI: 10.1111/j.1365-2435.2010.01757.x.

Allen BL., Allen LR., Leung LK. 2015. Interactions between two naturalised invasive predators 
476

477

495

496
Arias-Del Razo I., Hernández L., Laundré JWJ., Velasco-Vázquez L., Hernández L., Laundré JWJ. 2012. The landscape of fear: habitat use by a predator (Canis latrans) and its main prey (Lepus californicus and Sylvilagus audubonii). Canadian Journal of Zoology 90:683-693. DOI: $10.1139 / Z 2012-036$.

Bedoya-Perez MA., Carthey AJR., Mella VSA., McArthur C., Banks PB. 2013. A practical guide to avoid giving up on giving-up densities. Behavioral Ecology and Sociobiology 67:1541-1553. DOI: 10.1007/s00265-013-1609-3.

Berger-Tal O., Embar K., Kotler BP., Saltz D. 2015. Everybody loses : intraspecific competition induces tragedy of the commons in Allenby's gerbils. Ecology 96:54-61.

Beschta RL., Ripple WJ. 2009. Large predators and trophic cascades in terrestrial ecosystems of the western United States. Biological Conservation 142:2401-2414. DOI: 10.1016/j.biocon.2009.06.015.

Bleicher SS. 2014. Divergent behaviour amid convergent evolution: common garden experiments with desert rodents and vipers. Ph.D. Dissertation. University of Illinois at Chicago.

Bleicher SS., Brown JS., Embar K., Kotler BP. 2016. Novel predator recognition by Allenby’s gerbil (Gerbillus andersoni allenbyi): Do gerbils learn to respond to a snake that can "see" in the dark? Israel Journal of Ecology and Evolution:1-8. DOI: 10.1080/15659801.2016.1176614. 
497 Bleicher SS., Dickman CR. 2016. Bust economics: foragers choose high quality habitats in lean 498 times. PeerJ 1:1-15. DOI: 10.7717/peerj.1609.

499

500

501

502

503

504

505

506

507

508

509

510

511

512

513

514

515

516

517

Bleicher SS., Kotler BP., Brown JS. 2012. Comparing landscapes of fear in four desert rodents exposed to vipers and owls. International Mammalogical Congress XI, Belfast, UK (Poster).

Boyko AR., Gibson RM., Lucas JR., Boyko AR., Gibson RM., Lucas JR. 2004. How Predation Risk Affects the Temporal Dynamics of Avian Leks : Greater Sage Grouse versus Golden Eagles. The American Naturalist 163:154-165.

Brown JS. 1988. Patch use as an indicator of habitat preference, predation risk, and competition. Behavioral Ecology and Sociobiology 22:37-47. DOI: 10.1007/BF00395696.

Brown JS. 1999. Vigilance, patch use and habitat selection : Foraging under predation risk. Evolutionary Ecology Research 1:49-71.

Brown JS., Kotler BP. 2004. Hazardous duty pay and the foraging cost of predation. Ecology Letters 7:999-1014. DOI: 10.1111/j.1461-0248.2004.00661.x.

Brown JS., Laundré JW., Gurung M. 1999. The ecology of fear: optimal foraging, game theory, and trophic interactions. Journal of Mammalogy 80:385-399.

Chalfoun AD., Martin TE. 2009. Habitat structure mediates predation risk for sedentary prey: Experimental tests of alternative hypotheses. Journal of Animal Ecology 78:497-503. DOI: 10.1111/j.1365-2656.2008.01506.x.

Clinchy M., Zanette L., Charlier TD., Newman AEM., Schmidt KL., Boonstra R., Soma KK. 2011. Multiple measures elucidate glucocorticoid responses to environmental variation in predation threat. Oecologia 166:607-614. DOI: 10.1007/s00442-011-1915-2. 
518 Creel S., Dantzer B., Goymann W., Rubenstein DR. 2013. The ecology of stress: Effects of the

519 social environment. Functional Ecology 27:66-80. DOI: 10.1111/j.1365-

$520 \quad 2435.2012 .02029 . x$.

521 Dickman C. 1986. An experimental study of competition between two species of dasyurid 522 marsupials. Ecological Monographs 56:221-241.

523 Diamond JM. 1975. The island dilemma: Lessons of modern biogeographic studies for the 524 design of natural reserves. Biological Conservation 7:129-146. DOI: 10.1016/0006$525 \quad 3207(75) 90052-X$.

526 Druce DJ., Brown JS., Kerley GIH., Kotler BP., Mackey RL., Slotow R. 2009. Spatial and 527 temporal scaling in habitat utilization by klipspringers (Oreotragus oreotragus) determined $528 \quad$ using giving-up densities. Austral Ecology 34:577-587. DOI: 10.1111/j.14429993.2009.01963.x.

Dupuch A., Morris DW., Halliday WD. 2013. Patch use and vigilance by sympatric lemmings in 531 predator and competitor-driven landscapes of fear. Behavioral Ecology and Sociobiology

Embar K., Raveh A., Hoffmann I., Kotler BP. 2014. Predator facilitation or interference: a game of vipers and owls. Oecologia 174:1301-9. DOI: 10.1007/s00442-013-2760-2. 68:299-308. DOI: 10.1007/s00265-013-1645-z. albogularis erythrarchus, axes of fear through patch use. Animal Behaviour 81:455-462. DOI: 10.1016/j.anbehav.2010.11.018.

538 Fogarty S., Cote J., Sih A. 2011. Social Personality Polymorphism and the Spread of Invasive 
Species: A Model. The American Naturalist 177:273-287. DOI: 10.1086/658174.

540 Gallagher AJ., Creel S., Wilson RP., Cooke SJ. 2017. Energy Landscapes and the Landscape of

$541 \quad$ Fear. Trends in Ecology \& Evolution 32:88-96. DOI: 10.1016/j.tree.2016.10.010.

542 Glen AS., Dickman CR. 2005. Complex interactions among mammalian carnivores in Australia,

543 and their implications for wildlife management. Biological reviews of the Cambridge

$544 \quad$ Philosophical Society 80:387-401. DOI: 10.1017/s1464793105006718.

545 Hammerschlag N., Broderick AC., Coker JW., Coyne MS., Dodd M., Frick MG., Godfrey MH.,

546 Godley BJ., Griffin DB., Hartog K., Murphy SR., Murphy TM., Rose Nelson E., Williams

547 KL., Witt MJ., Hawkes LA. 2015. Evaluating the landscape of fear between apex predatory 548 sharks and mobile sea turtles across a large dynamic seascape. Ecology 96:2117-2126.

$549 \quad$ DOI: $10.1890 / 14-2113.1$.

550

551

552

553

554

555

556

557

558

559

Hassell MP. 1978. The dynamics of arthropod predator-prey systems. Princeton, NJ: Princeton University Press.

Haythornthwaite AS., Dickman CR. 2006. Long-distance movements by a small carnivorous marsupial: How Sminthopsis youngsoni (Marsupialia: Dasyuridae) uses habitat in an Australian sandridge desert. Journal of Zoology 270:543-549. DOI: 10.1111/j.14697998.2006.00186.x.

Heithaus MR., Frid A., Wirsing AJ., Dill LM., Fourqurean JW., Burkholder D., Thomson J., Bejder L. 2007. State-dependent risk-taking by green sea turtles mediates top-down effects of tiger shark intimidation in a marine ecosystem. Journal of Animal Ecology 76:837-844. DOI: $10.1111 /$ j.1365-2656.2007.01260.x. 
560 Ioannou CC., Payne M., Krause J. 2008. Predator effects on prey population dynamics in open

$561 \quad$ systems. Oecologia 157:177-182. DOI: 10.1007/s00442-008-.

562 Iribarren C., Kotler BP. 2012. Foraging patterns of habitat use reveal landscape of fear of Nubian 563 ibex Capra nubiana. Wildlife Biology 18:194-201. DOI: 10.2981/11-041.

564 Jacob J., Brown JS. 2000. Microhabitat Use, Giving-Up Densities and Temporal Activity as 565 Short- and Long-Term Anti-Predator Behaviors in Common Voles. Oikos 91:131-138.

566 Kauffman MJ., Varley N., Smith DW., Stahler DR., MacNulty DR., Boyce MS. 2007.

567 Landscape heterogeneity shapes predation in a newly restored predator-prey system.

568 Ecology Letters 10:690-700. DOI: 10.1111/j.1461-0248.2007.01059.x.

569 Kotler BP. 1984. Risk of predation and the structure of desert rodent communities. Ecology $570 \quad 65: 689-701$.

571 Kotler BP., Brown JS., Bleicher SS., Embar K. 2016. Intercontinental-wide consequences of 572 compromise-breaking adaptations: the case of desert rodents. Israel Journal of Ecology \& 573 Evolution 0:1-10.

574 Kotler BP., Brown JS., Dall SRX., Gresser S., Ganey D., Bouskila A. 2002. Foraging games 575 between gerbils and their predators : temporal dynamics of resource depletion and 576 apprehension in gerbils. Evolutionary Ecology Research 4:495-518.

577 Laundré JW., Calderas JMM., Hernández L. 2009. Foraging in the landscape of fear, the 578 predator's dilemma: Where should I hunt? The Open Ecology Journal 2:1-6.

579 Laundré JW., Hernández L., Altendorf KB. 2001. Wolves, elk, and bison: reestablishing the 580 "landscape of fear" in Yellowstone National Park, U.S.A. Canadian Journal of Zoology 
582

583

584

585

586

587

588

589

590

591

592

593

594

595

596

597

598

599

600

601

Laundré JW., Hernandez L., Lopez Medina P., Campanella A., Lopez-Portillo J., GonzolezRomero A., Grajales-Tam KM., Burke AM., Gronemeyer P., Browning DM. 2017. The landscape of fear : the missing link to understand top-down and bottom-up controls of prey abundance? Ecology 95:1141-1152. DOI: 10.1890/13-1083.1.

Laundré JW., Hernandez L., Ripple WJ. 2010. The landscape of fear: Ecological implications of being afraid. The Open Ecology Journal 3:1-7. DOI: 10.2174/1874213001003030001.

Madin EMP., Madin JS., Booth DJ. 2011. Landscape of fear visible from space. Scientific Reports 1:1-4. DOI: 10.1038/srep00014.

Manning AD., Gordon IJ., Ripple WJ. 2009. Restoring landscapes of fear with wolves in the Scottish Highlands. Biological Conservation 142:2314-2321. DOI: 10.1016/j.biocon.2009.05.007.

Massey J., Cubaynes S., Coulson T. 2013. Will central Wyoming elk stop migrating to Yellowstone, and should we care? Ecology 94:1271-1274.

Matassa CM., Trussell GC. 2011. Landscape of fear influences the relative importance of consumptive and nonconsumptive predator effects. Ecology 92:2258-2266. DOI: 10.1890/11-0424.1.

McGill BJ., Enquist BJ., Weiher E., Westoby M. 2006. Rebuilding community ecology from functional traits. Trends in Ecology and Evolution 21:178-185. DOI: 10.1016/j.tree.2006.02.002.

Mella VSA., Banks PB., Mcarthur C. 2014. Negotiating multiple cues of predation risk in a 
602 landscape of fear: What scares free-ranging brushtail possums? Journal of Zoology 294:22603 30. DOI: $10.1111 /$ jzo. 12146.

604 Morris DW. 2003. How can we apply theories of habitat selection to wildlife conservation and 605 management? Wildlife Research 30:303-319. DOI: 10.1071/WR02028.

606 Morris DW., Lundberg P. 2011. Pillars of evolution: fundamental principles of the eco607 evolutionary process. Oxford: Oxford University Press.

608 Murdoch WW., Oaten A. 1975. Predation and Population Stability. Advances in Ecological $609 \quad$ Research 9:1-131.

610 Paine RT. 1963. Food web complexity and species diversity. The American Naturalist 100:65$611 \quad$ 75. DOI: $10.2307 / 2678832$.

612 Raveh A., Kotler BP., Abramsky Z., Krasnov BR. 2011. Driven to distraction: detecting the 613 hidden costs of flea parasitism through foraging behaviour in gerbils. Ecology letters 14:47614 51. DOI: $10.1111 /$ j.1461-0248.2010.01549.x.

615 Real LA., Caraco T. 1986. Risk and foraging in stochastic environments: theory and evidence 616 Real. Annual Review of Ecology, Evolution, and Systematics 17:371-390.

617 Ripple WJ., Beschta RL. 2003. Wolf reintroduction, predation risk, and cottonwood recovery in $618 \quad$ Yellowstone National Park. Forest Ecology and Management 184:299-313. DOI: $619 \quad 10.1016 / \mathrm{S} 0378-1127(03) 00154-3$.

620 Ripple WJ., Beschta RL. 2004. Wolves and the Ecology of Fear: Can Predation Risk Structure 621 Ecosystems? BioScience 54:755-766. DOI: 10.1641/0006-

622 3568(2004)054[0755:WATEOF]2.0.CO;2. 
623 Ripple WJ., Beschta RL. 2012. Trophic cascades in Yellowstone: The first 15years after wolf 624 reintroduction. Biological Conservation 145:205-213. DOI: 10.1016/j.biocon.2011.11.005.

625 Ritchie EG., Johnson CN. 2009. Predator interactions, mesopredator release and biodiversity 626 conservation. Ecology Letters 12:982-998. DOI: 10.1111/j.1461-0248.2009.01347.x.

627 Roper JJ., Sullivan KA., Ricklefs RE. 2010. Avoid nest predation when predation rates are low, 628 and other lessons : testing the tropical - temperate nest predation paradigm. Oikos: 719729. DOI: 10.1111/j.1600-0706.2009.18047.x.

630

631

632

633

634

635

636

637

638

639

640

641

642

643

Rosenzweig ML. 1973. Habitat selection experiments with a pair of coexisting Heteromyid rodent species. Ecology 54:111-117.

Rosenzweig ML., Abramsky Z., Subach A. 1997. Safety in numbers: sophisticated vigilance by Allenby's gerbil. Proceedings of the National Academy of Sciences of the United States of America 94:5713-5715. DOI: 10.1073/pnas.94.11.5713.

Rosenzweig, ML., MacArthur R. 1963. Graphical Represenation and Stability Conditions of Predator-Prey Interactions. American Naturalist 97:209-223. DOI: 10.1086/282272.

Rypstra AL., Schmidt JM., Reif BD., Devito J., Matthew H., Rypstra AL., Schmidt JM., Reif BD., Devito J., Persons MH. 2007. Tradeoffs Involved in Site Selection and Foraging in a Wolf Spider : Effects of Substrate Structure and Predation Risk. Oikos 116:853-863.

Shrader AM., Brown JS., Kerley GIH., Kotler BP. 2008. Do free-ranging domestic goats show "landscapes of fear"? Patch use in response to habitat features and predator cues. Journal of Arid Environments 72:1811-1819. DOI: 10.1016/j.jaridenv.2008.05.004.

Sih A., Englund G., Wooster D. 1998. Emergent impacts of mulitple predators on prey. TREE 
645 Suraci JP., Clinchy M., Dill LM., Roberts D., Zanette LY. 2016. Fear of large carnivores causes 646 a trophic cascade. Nature Communications 7:10698. DOI: 10.1038/ncomms10698.

647 Tadesse S., Kotler BP. 2011. Seasonal Habitat Use by Nuian Ibex (Capra nubiana) evaluated 648 with behavioral indicators. Israel Journal of Ecology and Evolution 57:223-246.

649 Uexküll JJ. 1909. Umwelt und Innenwelt der Tiere [Environment and inner world of animals]. 650 Foundations of Comparative Ethology: 222-245.

651 Van Der Merwe M., Brown JS. 2008. Mapping the landscape of fear of the cape ground squirrel 652 (Xerus inauris). Journal of Mammalogy 89:1162-1169. DOI: 10.1644/08-MAMM-A-035.1.

653 Vincent TL., Brown JS. 2005. Evolutionary game theory, natural selection, and Darwinian 654 dynamics. Cambridge University Press.

655 Willems EP., Hill RA. 2009. Predator-Specific Landscapes of Fear and Resource Distribution : 656 Effects on Spatial Range Use. Ecology 90:546-555.

657 Zanette L., Jenkins B. 2000. Nesting success and nest predators in forest fragments : A study 658 using real and artificial nests. The Auk 117:445-454.

659 Zanette LY., White AF., Allen MC., Clinchy M. 2011. Perceived predation risk reduces the 660 number of offspring songbirds produce per year. Science 334:1398-1402.

661

662

663 


\section{Figure Legends}

665 Figure 1. Cumulative number of manuscripts using the "landscape of fear" (LOF) as a 666 significant descriptor of the study in the title, abstract or key-words. The Buzz-Word category is 667 a classification of manuscripts that defined the LOF in a way that differed from a spatial 668 distribution of a populations' (or individuals') behavioral response to the perceived balance of 669 resources and risk of predation.*Only manuscripts published between January-April 2017.

670 Figure 2. Example of Landscape of Fear Map using a dataset adapted from Bleicher et al.

671 (2016). The map shows the distribution of risk using giving up densities (GUDs) for a population 672 of Allenby's gerbils (G. andersoni allenbyi) in a controlled enclosure in Sde Boker, Israel. The 673 contour lines are derived using the distance weighted least squares (DWLS) smoothing function 674 at a tension of 0.5 . GUD values above $2.0 \mathrm{~g}$ (orange and red) reflect areas that are perceived as 675 dangerous by the gerbils while areas below $1.0 \mathrm{~g}$ (green and blue) reflect zones of safety. The + 676 signs are the locations in which the data was collected and both $\mathrm{x}$ and $\mathrm{y}$-exes are measuring the 677 enclosure in meters. 
680 Figure 1.

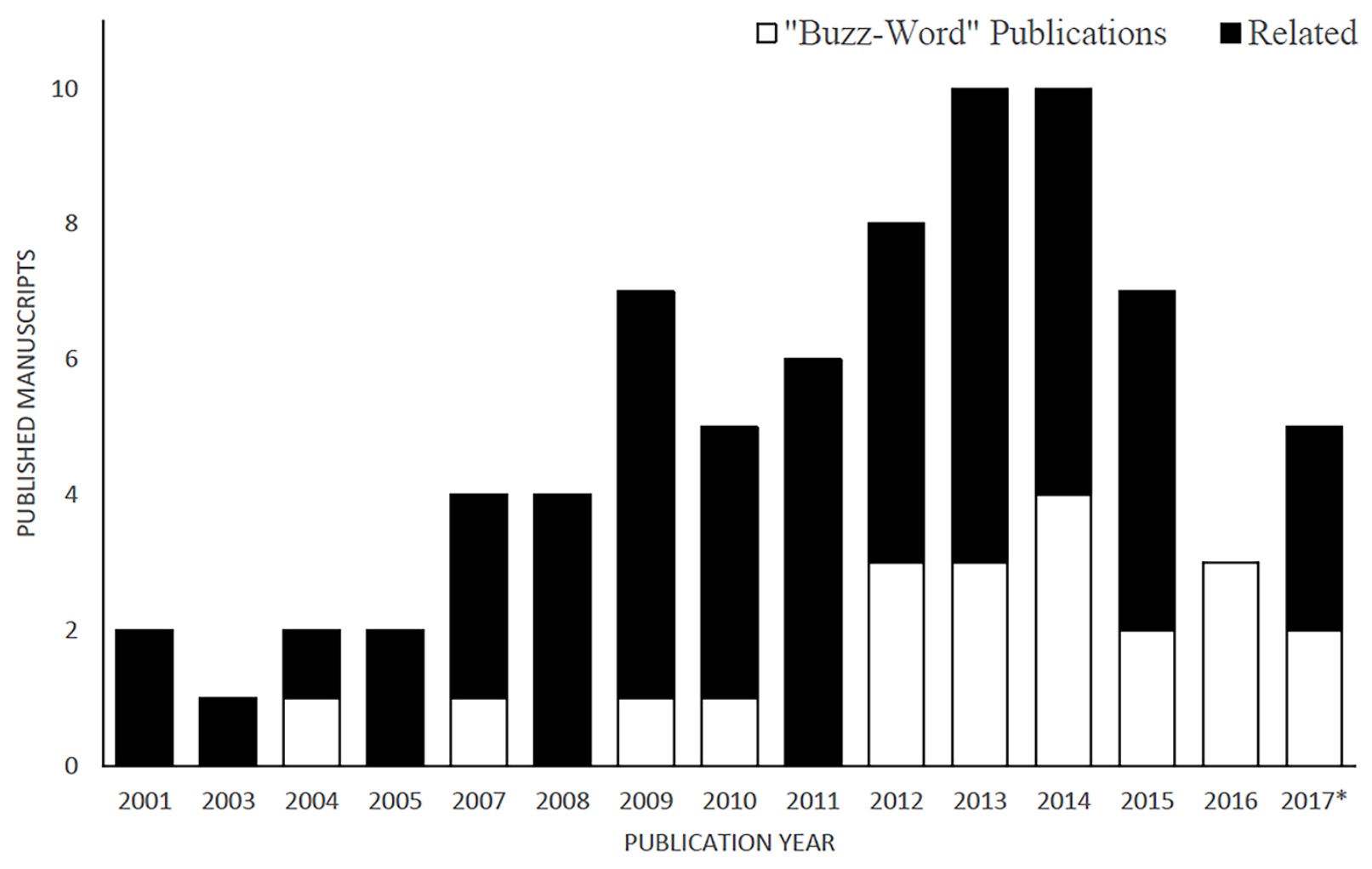

681

682 
683 Figure 2

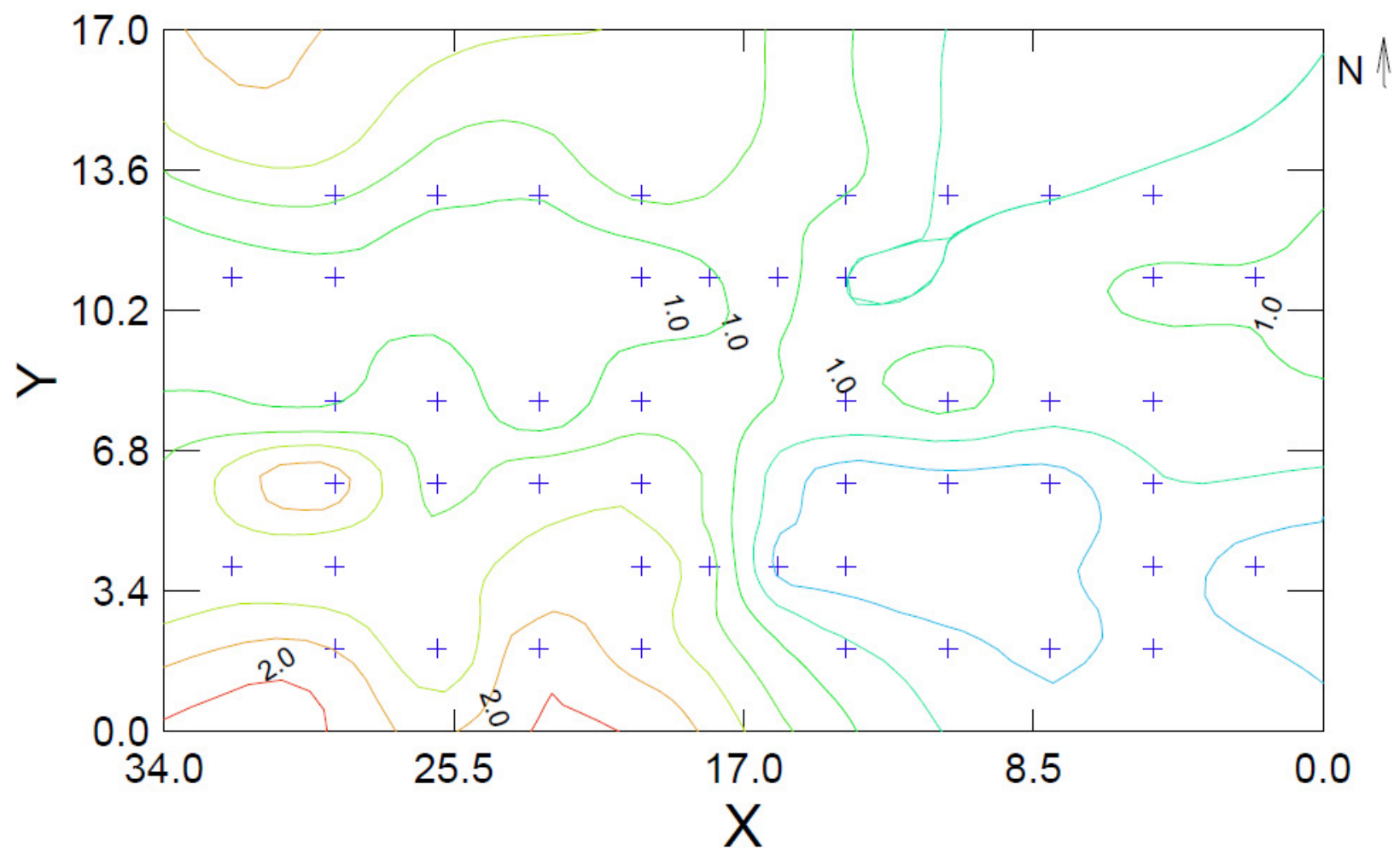


685

686 Table 1. Summary table for all published manuscripts using the term "landscape of fear" (in title, abstract 687 or key words), and distinction of manuscripts misinterpreting the term as "Buzz-Word" manuscripts.

688

\begin{tabular}{|c|c|c|c|}
\hline & & Total Manuscripts & \% Buzz-Word (\# of publications) \\
\hline \multicolumn{4}{|c|}{ A. Manuscripts using the LOF concept: } \\
\hline & & 78 & $26.9 \%(21)$ \\
\hline \multicolumn{4}{|c|}{ B. Published in a journal covering: } \\
\hline & General Ecology & $44^{*}$ & $14 \%(6)$ \\
\hline & Zoology & $15^{*}$ & $7 \%(1)$ \\
\hline & Animal Behavior & $9 *$ & $22 \%(2)$ \\
\hline & $\begin{array}{l}\text { Applied Ecology /Wildlife } \\
\text { Management }\end{array}$ & 9 & $45 \%(4)$ \\
\hline & General Biology & 8 & $75 \%(6)$ \\
\hline & Evolution & 3 & $67 \%(2)$ \\
\hline \multicolumn{4}{|c|}{ C. Manuscript Type : } \\
\hline & Opinion & 8 & $25 \%(2)$ \\
\hline & Review & 12 & $25 \%(3)$ \\
\hline & Empirical & 58 & $28 \%(16)$ \\
\hline \multicolumn{4}{|c|}{ D. Manuscript Defines The LOF as a: } \\
\hline & Landscape Trait & $23^{* *}$ & $31 \%(7)$ \\
\hline & Individuals' trait & $15^{* *}$ & $33 \%(5)$ \\
\hline & Populations' trait & $49^{* *}$ & $12 \%(6)$ \\
\hline \multicolumn{4}{|c|}{$\begin{array}{l}\text { * Some manuscripts are counted more than one time if journals cover a variety of fields (e.g. Journal of } \\
\text { Animal Ecology is categorized both as general ecology and zoology).** Some manuscripts have } \\
\text { conflicting definitions or apply the LOF to describe a characteristic of multiple levels and are thus } \\
\text { counted more than one time. }\end{array}$} \\
\hline
\end{tabular}


690

691 Table 2 - Theoretical development of the LOF as a research program. *these references to the 692 LOF were published prior to the seminal paper Laundré et al 2001, however are regularly cited 693 as influential papers in the field, or had referenced the seminal paper as unpublished work.

\begin{tabular}{|c|c|c|}
\hline Year & Manuscript & Major Theoretical Contribution \\
\hline 2000 & $\begin{array}{l}\text { (Jacob \& Brown, 2000) } \\
\text { (Zanette \& Jenkins, 2000) }\end{array}$ & $\begin{array}{l}\text { - The LOF combines both spatial and temporal } \\
\text { assessments of risk } \\
\text { - The LOF is a measure of distribution of stress within } \\
\text { a physical landscape based on habitat quality }\end{array}$ \\
\hline 2001 & $\begin{array}{l}\text { (Laundré, Hernández \& } \\
\text { Altendorf, 2001) }\end{array}$ & $\begin{array}{l}\text { Defining the LOF framework as the impact of } \\
\text { relative danger in shaping prey behavior and habitat } \\
\text { selection. }\end{array}$ \\
\hline 2004 & $\begin{array}{l}\text { (Brown \& Kotler, 2004) } \\
\text { (Ripple \& Beschta, 2004) }\end{array}$ & $\begin{array}{l}\text { LOF changed based on levels of risk: predator } \\
\text { community or predator activity levels. } \\
\text { - Linking food webs to the ecology of fear through } \\
\text { examples where fear of wolves trickled down to } \\
\text { increase in vegetation diversity (and where it did not. }\end{array}$ \\
\hline 2007 & $\begin{array}{l}\text { (Kauffman et al., 2007) } \\
\text { (Rypstra et al., 2007) } \\
\text { (Heithaus et al., 2007) }\end{array}$ & $\begin{array}{l}\text { - Predators tap into prey LOF in hunting site selection. } \\
\text { - The individual effect: intra-species completion and } \\
\text { cannibalism affect the populations LOF. } \\
\text { - Behavioral state: health of individual affects its LOF. }\end{array}$ \\
\hline 2008 & $\begin{array}{l}\text { (Van Der Merwe \& Brown, } \\
\text { 2008) }\end{array}$ & $\begin{array}{l}\text { The LOF as a cost benefit analysis of energy; } \\
\text { measuring a LOF in kJ. }\end{array}$ \\
\hline 2009 & $\begin{array}{l}\text { (Druce et al., 2009) } \\
\text { (Ritchie \& Johnson, 2009) } \\
\text { (Willems \& Hill, 2009) }\end{array}$ & $\begin{array}{l}\text { Defining spatial and temporal scales as drivers of } \\
\text { change in LOFs } \\
\text { - Studying inter-guild competition using the LOF } \\
\text { framework (apex-mesopredators) } \\
\text { - Information based LOF's- signals for specific } \\
\text { predators. }\end{array}$ \\
\hline 2011 & (Matassa \& Trussell, 2011) & $\begin{array}{l}\text { - Using survivorship as a measure of non-consumptive } \\
\text { predator effects on both spatial and temporal scales. }\end{array}$ \\
\hline 2013 & $\begin{array}{l}\text { (Dupuch, Morris \& Halliday, } \\
\text { 2013) }\end{array}$ & $\begin{array}{l}\text { Using the LOF as a tools to compare competition } \\
\text { pressures and predation risk. }\end{array}$ \\
\hline 2014 & (Bleicher, 2014) & $\begin{array}{l}\text { - Defining LOF shape and plasticity; The LOF as a } \\
\text { tool for macroevolutionary comparison. }\end{array}$ \\
\hline 2015 & (Hammerschlag et al., 2015) & $\begin{array}{l}\text { - Linking activity patterns of predators the LOF of } \\
\text { prey on a temporal scale. }\end{array}$ \\
\hline \multirow[t]{2}{*}{2017} & (Laundré et al., 2017) & $\begin{array}{l}\text { Comparing bottom-up and top-down models of } \\
\text { population dynamics using the LOF framework. }\end{array}$ \\
\hline & (Gallagher et al., 2017) & - Combining LOF and energy landscapes as one unit. \\
\hline
\end{tabular}




\begin{tabular}{|c|c|c|c|c|c|c|c|c|c|}
\hline (A) & \multicolumn{9}{|c|}{ Continent } \\
\hline $\begin{array}{l}\mathrm{S} \\
\mathrm{t}\end{array}$ & (A) & $\begin{array}{l}\text { N. } \\
\text { America }\end{array}$ & $\begin{array}{l}\text { Africa/ } \\
\text { Sahara }\end{array}$ & Australia & Europe & Asia/Polynesia & & & Total \\
\hline $\begin{array}{l}\mathrm{u} \\
\mathrm{d}\end{array}$ & $\begin{array}{l}\text { Alpine } \\
\text { Scrubland }\end{array}$ & 9 & 4 & & & & & & 13 \\
\hline $\mathrm{y}$ & Arid/ Tundra & 4 & 8 & & & & & & 12 \\
\hline $\mathrm{S}$ & $\begin{array}{l}\text { Temperate } \\
\text { Forest }\end{array}$ & 1 & & 2 & 3 & & & & 6 \\
\hline $\begin{array}{l}\mathrm{y} \\
\mathrm{s}\end{array}$ & $\begin{array}{l}\text { Grassland/ } \\
\text { Savannah }\end{array}$ & 1 & 3 & & 1 & & & & 5 \\
\hline $\mathrm{t}$ & Marine & 2 & & 1 & & 1 & & & 4 \\
\hline e & Anthropocentric & & & & 1 & 1 & & & 2 \\
\hline $\mathrm{m}$ & Total & 17 & 15 & 3 & 5 & 2 & & & 42 \\
\hline (B) & \multicolumn{9}{|c|}{ Focal Organism } \\
\hline $\begin{array}{l}\mathrm{M} \\
\mathrm{e}\end{array}$ & (B) & $\begin{array}{l}\text { Ungulat } \\
\text { e }\end{array}$ & $\begin{array}{l}\text { Small } \\
\text { Mammal }\end{array}$ & Predators* & Primates & $\begin{array}{l}\text { Marine } \\
\text { Herbivores** }\end{array}$ & $\begin{array}{l}\text { Vegetation } \\
* * *\end{array}$ & Birds & Total \\
\hline $\mathrm{a}$ & GUD & 6 & 13 & 1 & 4 & 1 & 1 & & 26 \\
\hline $\mathrm{s}$ & Occupancy & 2 & 1 & 2 & & 1 & & & 6 \\
\hline $\mathrm{u}$ & Scat Density & 2 & 1 & & & & & & 3 \\
\hline $\mathrm{r}$ & Telemetry & 1 & & 1 & & 1 & & & 3 \\
\hline e & Vigilance & 3 & & & & & & & 3 \\
\hline $\mathrm{m}$ & Others & 1 & & & & & 1 & 1 & 3 \\
\hline $\begin{array}{l}\mathrm{e} \\
\mathrm{n} \\
\mathrm{t} \\
\mathrm{V} \\
\mathrm{a} \\
\mathrm{r} \\
\mathrm{i} \\
\mathrm{a} \\
\mathrm{b} \\
\mathrm{l} \\
\mathrm{e}\end{array}$ & Total & 15 & 15 & 4 & 4 & 3 & 2 & 1 & 44 \\
\hline
\end{tabular}

696 *both mesopredators and apex predators.**multiple studies used grazing reef fish as a group as 697 opposed with a specific species. ${ }^{* * *}$ Damage to algae or woody vegetation. 
699 Table 4. Distribution of manuscripts by trophic levels studied

700

No. of Publications

\begin{tabular}{lc}
\hline A. Number of Trophic Levels in Study \\
\hline 1 trophic level & 20 \\
2 trophic levels & 23 \\
3 trophic levels & 6 \\
\hline B. Trophic Level Studied & \\
\hline Humans & 1 \\
Apex-predators & 2 \\
Carnivore & 49 \\
Herbivore (granivore) & 31 \\
Vegetation & 10 \\
$* *$ Non Biotic & 1 \\
01 &
\end{tabular}

702 


\section{A. Trophic cascades}

The world is green because predators control the populations of grazing species concluded Hairston (Hairston, Smith \& Slobodkin, 1960) in what later became known as the

"Green World Hypothesis". Since this ground-breaking paper, a large focus in community ecology was directed at the study of trophic cascades, i.e. the idea that through direct predation the size of a population impacts multiple trophic levels below it and the size of the population of prey dictates the availability of resources that sustain the predators above them.

The textbook example used to teach these interactions is population fluxes in LotkaVolterra of lynx-hare (and mastings) predator-prey cycles in Canadian boreal forests (Hewitt, 1921; Fox \& Bryant, 1984; Krebs et al., 1995; Lima, 1998). This example highlights the trophic cascades from a bottom-up perspective, i.e. how the availability of resources influences the populations of predators. Resource availability dictates the availability of niches for species to occupy in the community (Vincent \& Brown, 2005). However, the top-down interactions greatly dictate the traits the species must have to survive within those niches. Robert Paine pioneered the study of the predation implications on prey when he described how a diverse predator community results in diverse prey community (Paine, 1963). In this example, the predation pressure from multiple intertidal zone predators (sea stars) removed the competitive ability of the dominant barnacles and allowed for higher mollusk diversity. More recently, Schmitz and Price (2011) showed a strong positive correlation between the biomass of arachnid predators on the vegetation biomass in an agricultural system. In this system, spiders feed on grasshoppers that damage vegetation. The biomass of spiders thus positively correlates with the health of the vegetation crop. These examples show that the predators negatively affect the prey populations 
726 and thus indirectly have positive effects on the vegetation. However, consumptive-effects did not

727 entirely explain how predators control prey (and vice-versa). Thus a study of non-consumptive

728 predator effects was created, named the "ecology of fear" by Joel Brown (Brown, Laundré \&

729 Gurung, 1999), with the aim to answer two major questions: (1) Do predators control the

730 populations of prey solely by consuming them? And (2) would the evolution of prey species to

731 manage the risk of predation not overcome the negative impacts these predators have on their

732 prey populations?

733

734

735

736

737

738

739

740

741

742

743

744

745

746

747

748

\section{B. Non- Consumptive Effects of Predators: an "Ecology of Fear"}

One does not have to study wildlife behavior to understand the effects predation risk has on animal behavior. All one has to do, is think of our own body's response to a risky situation.

Our bodies instinctively respond to the risk in the environment by producing stress hormones.

This production results in increased blood pressure, pulse and sensory sensitivity. In essence, our bodies tell us to get out of harm's way as fast as we can. In this example of our own day-to-day life we find the evidence for the millions of years evolutionary race between predators and prey to maintain the energetic needs of both groups. Prey evolve mechanisms to avoid the risk, and predators find ways to out-gun these defense mechanisms.

In non-human examples we expect that predators would have to find a balance between over-hunting a naïve food resource into extinction and starvation from aiming to hunt highly vigilant prey (Brown \& Vincent, 1992; Lima, 1998, 2002; Brown, Laundré \& Gurung, 1999; Wolf \& Mangel, 2007). The evolutionary arms-race between the predators and their prey results in predators managing the fear of the prey into an optimal state of vigilance by limiting their encounter rates (Embar, Mukherjee \& Kotler, 2014). Overstimulating the perception of risk in the prey, would lower the hunting success of the predator to unsustainable levels. Meanwhile, the 
749 prey species evolved to counteract the predator management through a variety of behavioural

750 strategies, or choices. I will examine a few case studies of such strategies.

751

752

753

754

755

756

757

758

759

760

761

762

763

764

765

766

767

768

769

770

771

Many species choose their habitat based on the risk which this habitat poses to them. For example, heteromyid rodents choose habitat based on the density of vegetation. Species (kangaroo rats) that can hop out of harm's way prefer the un-encumbered open, and species that are limited in predator evasion strategies (pocket mice) find shelter under thick vegetation (Rosenzweig, 1973). In kangaroo rats specifically the presence of vipers was shown to be a driver of the choice of the open habitat (Bouskila, 1995). In another example, Gerbilline rodents responded to owls with clear preference for sheltered microhabitats (Kotler, Blaustein \& Brown, 1992; Abramsky et al., 1996; Abramsky, Rosenzweig \& Subach, 1997; Kotler et al., 2002; St. Juliana et al., 2011; Embar et al., 2014). Habitat fragmentation, or edge effect, has been shown to affect the habitat use (predominantly in the form of avoidance) by songbirds (Storch, Woitke \& Krieger, 2005; Fischer \& Lindenmayer, 2007). Larger animals (ungulates and primates) have been shown to select habitat where the sightlines allow good visibility of approaching predators (Tadesse, 2012; Abu Baker \& Brown, 2013; Coleman \& Hill, 2014). Lastly, a number of studies studying wolf-elk interactions show that based on habitat variability the strategies applied by the elk to avoid predation (vigilance, habitat selection) can vary greatly (Hebblewhite, Merrill \& McDonald, 2005; Eisenberg et al., 2014) equipped for risk management (kangaroo rats) have a more diverse diet than the foragers less well equipped for predator management (pocket mice) who forage what they can (Davidson, Brown \& Inouye, 1980). In another example, in the Simpson Desert, dasyurid marsupials avoid 
772 risk by covering large distances to search for refuge. These small mammals (20 grams on

773 average) inhabit burrows in the swale of sand dunes located away from the resource dense

774 habitats at the dune crests (Haythornthwaite, 2005; Haythornthwaite \& Dickman, 2006). All of

775 these adaptations clearly suggest that a trade-off between resources and predation risk occurs

776 within a spatial dynamic, and as such these predator-prey games can and should be studied using

777 a spatial analysis, a "landscape of fear" (LOF).

This conceptual framework was expanded to study the effects of landscape heterogeneity

779 (Brown \& Kotler, 2004) culminating in measured maps combining vegetation, refuge, resource

780 availability and risk. In an example with cape ground squirrels (Xerus inauris), the LOF was

781 interpreted as a cost benefit analysis of energetic values over change in the landscape (Joules/

782 meter) (Van Der Merwe \& Brown, 2008). This conversion allowed researchers to weigh the

783 study of energetic gain from food patches and compare those gains to the cost of risk avoidance

784 (cf. Brown, 1988)

785 Sources Used

786 Abramsky Z., Rosenzweig ML., Subach A. 1997. Gerbils under threat of owl predation :

787 isoclines and isodars. Oikos 78:81-90.

788

789

790

791

792

793
Abramsky Z., Strauss E., Subach A., Riechman A., Kotler BP. 1996. The effect of barn owls (Tyto alba) on the activity and microhabitat selection of Gerbillus allenbyi and G. pyramidum. Oecologia 105:313-319. DOI: 10.1007/BF00328733.

Abu Baker M., Brown JS. 2013. Foraging and habitat use of common duikers, Sylvicapra grimmia, in a heterogeneous environment within the Soutpansberg, South Africa. African Journal of Ecology 52:1-10. 
794 Bouskila A. 1995. Interactions between predation risk and competition : a field study of $795 \quad$ kangaroo rats and snakes. Ecology 76:165-178.

796

797

798

799

800

801

802

803

804

805

806

807

808

809

810

811

812

813

814

Brown JS. 1988. Patch use as an indicator of habitat preference, predation risk, and competition. Behavioral Ecology and Sociobiology 22:37-47. DOI: 10.1007/BF00395696.

Brown JS., Kotler BP. 2004. Hazardous duty pay and the foraging cost of predation. Ecology Letters 7:999-1014. DOI: 10.1111/j.1461-0248.2004.00661.x.

Brown JS., Laundré JW., Gurung M. 1999. The ecology of fear: optimal foraging, game theory, and trophic interactions. Journal of Mammalogy 80:385-399.

Brown JS., Vincent TL. 1992. Organization of predator-prey communities as an evolutionary game. Evolution 46:1269-1283.

Coleman BT., Hill RA. 2014. Living in a landscape of fear: the impact of predation, resource availability and habitat structure on primate range use. Animal Behaviour 88:165-173. DOI: 10.1016/j.anbehav.2013.11.027.

Davidson DW., Brown JH., Inouye RS. 1980. Competition and the structure of granivore communities. BioScience 30:233-238.

Eisenberg C., Hibbs DE., Ripple WJ., Salwasser H. 2014. Context dependence of elk ( Cervus elaphus ) vigilance and wolf ( Canis lupus ) predation risk. Canadian Journal of Zoology 92:727-736. DOI: 10.1139/cjz-2014-0049.

Embar K., Mukherjee S., Kotler BP. 2014. What do predators really want? The role of gerbil energetic state in determining prey choice by Barn Owls. Ecology 95:280-285. 
of vipers and owls. Oecologia 174:1301-9. DOI: 10.1007/s00442-013-2760-2.

816 Fischer J., Lindenmayer DB. 2007. Landscape modification and habitat fragmentation : a

817 synthesis. Global Ecology and Biogeography 16:265-280. DOI: 10.1111/j.1466-

$818 \quad$ 8238.2006.00287.x.

819 Fox JF., Bryant JP. 1984. Instability of the snowshoe hare and woody plant interaction.

820 Oecologia 63:128-135. DOI: 10.1007/BF00379794.

821 Hairston NG., Smith FE., Slobodkin LB. 1960. Community structure, population control, and

822 competition. American Naturalist 94:421-425. DOI: 10.1086/521238.

823 Haythornthwaite AS. 2005. Microhabitat use and foraging behaviour of Sminthopsis youngsoni

824 (Marsupialia : Dasyuridae) in arid central Australia. Wildlife Research 32:609-615. DOI:

$825 \quad$ 10.1071/WR04126.

826 Haythornthwaite AS., Dickman CR. 2006. Long-distance movements by a small carnivorous 827 marsupial: How Sminthopsis youngsoni (Marsupialia: Dasyuridae) uses habitat in an 828 Australian sandridge desert. Journal of Zoology 270:543-549. DOI: 10.1111/j.1469$829 \quad 7998.2006 .00186 . x$.

830

831

832

833

834

835

Hebblewhite M., Merrill EH., McDonald TL. 2005. Spatial Decomposition of Predation Risk Using Resource Selection Functions : An Example in a Wolf-Elk Predator-Prey System. Oikos 111:101-111.

Hewitt CG. 1921. In The Conservation of the Wild Life of Canada. New York, New York: Charles Scribner's Sons.

St. Juliana J., Kotler BP., Brown JS., Mukherjee S., Bouskila A. 2011. The foraging response of 

gerbils to a gradient of owl numbers. Evolutionary Ecology Research 13:869-878.

837 Kotler BP., Blaustein L., Brown JS. 1992. Predator Facilitation: the combined effect of snakes 838 and owls on the foraging behavior of gerbils. Annals of Zoology Fennici 29:199-206.

839 Kotler BP., Brown JS., Dall SRX., Gresser S., Ganey D., Bouskila A. 2002. Foraging games

840 between gerbils and their predators : temporal dynamics of resource depletion and $841 \quad$ apprehension in gerbils. Evolutionary Ecology Research 4:495-518.

842 Krebs CJ., Boutin S., Boonstra R., Sinclair a R., Smith JN., Dale MR., Martin K., Turkington R. 843 1995. Impact of food and predation on the snowshoe hare cycle. Science 269:1112-1115. $844 \quad$ DOI: $10.1126 /$ science.269.5227.1112.

Lima SL. 1998. Nonlethal effects in the ecology of predator-prey interactions. BioScience 48:2534. DOI: $10.2307 / 1313225$. (Xerus inauris). Journal of Mammalogy 89:1162-1169. DOI: 10.1644/08-MAMM-A-035.1.

Paine RT. 1963. Food web complexity and species diversity. The American Naturalist 100:6575. DOI: $10.2307 / 2678832$.

Rosenzweig ML. 1973. Habitat selection experiments with a pair of coexisting Heteromyid rodent species. Ecology 54:111-117.

855 Schmitz OJ., Price JR. 2011. Convergence of trophic interaction strengths in grassland food webs through metabolic scaling of herbivore biomass. Journal of Animal Ecology 80:1330- 
858 Storch I., Woitke E., Krieger S. 2005. Landscape-scale edge effect in predation risk in forest859 farmland mosaics of central Europe7. Landscape Ecology 20:927-940. DOI:

860 10.1007/s10980-005-7005-2.

861

Tadesse S. 2012. Habitat quality and foraging ecology of Mountain Nyala (Tragelaphus buxtoni)

862 in the Munessa Forest and the Bale Mountains National Park, South-Eastern Ethiopia. Ph.D.

863 Dissertation. Ben Gurion University of the Negev.

864 Vincent TL., Brown JS. 2005. Evolutionary game theory, natural selection, and Darwinian 865 dynamics. Cambridge, Cambridge University Press.

866 Wolf N., Mangel M. 2007. Strategy, compromise, and cheating in predator - prey games.

867 Evolutionary Ecology Research 9:1293-1304. 


\section{Appendix II. Bibliography of manuscripts reviewed for this analysis}

869

870

871

872

873

874

875

876

877

878

879

880

881

882

883

884

885

886

887

888

Abu Baker MA., Brown JS. 2010. Islands of fear: effects of wooded patches on habitat suitability of the striped mouse in a South African grassland. Functional Ecology 24:13131322. DOI: $10.1111 / \mathrm{j} .1365-2435.2010 .01757 . x$.

Abu Baker M a., Brown JS. 2011. Variation of within-day foraging costs in the striped mouse (Rhabdomys pumilio). Mammalian Biology 76:654-656. DOI:

$$
\text { 10.1016/j.mambio.2011.02.005. }
$$

Abu Baker M., Brown JS. 2013. Foraging and habitat use of common duikers, Sylvicapra grimmia, in a heterogeneous environment within the Soutpansberg, South Africa. African Journal of Ecology 52:1-10.

Altendorf KB., Laundré JW., Lopez Gonzalez CA., Brown JS., González CAL., Brown JS. 2001. Assessing effects of predation risk on foraging behavior of mule deer. Journal of Mammalogy 82:430-439.

Arias-Del Razo I., Hernández L., Laundré JWJ., Velasco-Vázquez L., Hernández L., Laundré JWJ. 2012. The landscape of fear: habitat use by a predator (Canis latrans) and its main prey (Lepus californicus and Sylvilagus audubonii). Canadian Journal of Zoology 90:683693. DOI: 10.1139/Z2012-036.

Atkins A., Redpath SM., Little RM., Amar A. 2017. Experimentally Manipulating the Landscape of Fear to Manage Problem Animals. The Journal of Wildlife Management 81:610-616. DOI: $10.1002 /$ jwmg.21227.

Bedoya-Perez MA., Carthey AJR., Mella VSA., McArthur C., Banks PB. 2013. A practical 
889

890

891

892

893

894

895

896

897

898

899

900

901

902

903

904

905

906

907

908

909

guide to avoid giving up on giving-up densities. Behavioral Ecology and Sociobiology 67:1541-1553. DOI: 10.1007/s00265-013-1609-3.

Benhaiem S., Delon M., Lourtet B., Cargnelutti B., Aulagnier S., Hewison AM., Morellet N., Verheyden H. 2008. Hunting increases vigilance levels in roe deer and modifies feeding site selection. Animal Behaviour 76:611-618. DOI: 10.1016/j.anbehav.2008.03.012.

Beschta RL., Ripple WJ. 2013. Are wolves saving Yellowstone's aspen? A landscape-level test of a behaviorally mediated trophic cascade : comment. Ecology 94:1420-1425.

Blanchard P., Lauzeral C., Chamille-Jammes S., Yoccoz NG., Pontier D. 2016. Analyzing the proximity to cover in a landscape of fear: a new approach applied to fine-scale habitat use by rabbits facing feral cat predation on Kerguelen archipelago. PeerJ 1:1-16.

Bleicher SS. 2014. Divergent behaviour amid convergent evolution: common garden experiments with desert rodents and vipers. Ph.D. Dissertation. University of Illinois at Chicago.

Breviglieri CPB., Piccoli GCO., Uieda W., Romero GQ. 2013. Predation-risk effects of predator identity on the foraging behaviors of frugivorous bats. Oecologia 173:905-912. DOI: 10.1007/s00442-013-2677-9.

Brook LA., Johnson CN., Ritchie EG. 2012. Effects of predator control on behaviour of an apex predator and indirect consequences for mesopredator suppression. Journal of Applied Ecology 49:1278-1286. DOI: 10.1111/j.1365-2664.2012.02207.x.

Brown JS. 2010. Ecology of fear. In: Breed MD, Moore J eds. Encyclopedia of Animal Behaviour. Oxford: Elsevier Ltd, 581-587. 
910 Brown JS., Kotler BP. 2004. Hazardous duty pay and the foraging cost of predation. Ecology

911 Letters 7:999-1014. DOI: 10.1111/j.1461-0248.2004.00661.x.

912 Ciuti S., Muhly TB., Paton DG., McDevitt AD., Musiani M., Boyce MS. 2012a. Human

913 selection of elk behavioural traits in a landscape of fear. Proceedings. Biological sciences /

914 The Royal Society 279:4407-4416. DOI: 10.1098/rspb.2012.1483.

915 Ciuti S., Northrup JM., Muhly TB., Simi S., Musiani M., Pitt JA., Boyce MS. 2012b. Effects of

916 Humans on Behaviour of Wildlife Exceed Those of Natural Predators in a Landscape of

917 Fear. PLoS ONE 7. DOI: 10.1371/journal.pone.0050611.

918 Coleman BT., Hill RA. 2014. Living in a landscape of fear: the impact of predation, resource 919 availability and habitat structure on primate range use. Animal Behaviour 88:165-173. DOI:

$920 \quad$ 10.1016/j.anbehav.2013.11.027.

921 Cromsigt JPGM., Kuijper DPJ., Adam M., Beschta RL., Churski M., Eycott A., Kerley GIH.,

922 Mysterud A., Schmidt K., West K. 2013. Hunting for fear: innovating management of 923 human-wildlife conflicts. Journal of Applied Ecology 50:544-549. DOI: 10.1111/1365$924 \quad 2664.12076$.

925

926

927

928

929

930

931

Druce DJ., Brown JS., Kerley GIH., Kotler BP., Mackey RL., Slotow R. 2009. Spatial and temporal scaling in habitat utilization by klipspringers (Oreotragus oreotragus) determined using giving-up densities. Austral Ecology 34:577-587. DOI: 10.1111/j.14429993.2009.01963.x.

Dupuch A., Morris DW., Ale SB., Wilson DJ., Moore DE. 2014. Landscapes of fear or competition? Predation did not alter habitat choice by Arctic rodents. Oecologia 174:403412. DOI: $10.1007 / \mathrm{s} 00442-013-2792-7$. 
932 Dupuch A., Morris DW., Halliday WD. 2013. Patch use and vigilance by sympatric lemmings in 933 predator and competitor-driven landscapes of fear. Behavioral Ecology and Sociobiology 68:299-308. DOI: 10.1007/s00265-013-1645-z.

935 Eccard J a., Liesenjohann T. 2014. The importance of predation risk and missed opportunity 936 costs for context-dependent foraging patterns. PLoS ONE 9:1-5. DOI: 10.1371/journal.pone.0094107.

Embar K., Kotler BP., Mukherjee S. 2011. Risk management in optimal foragers: the effect of sightlines and predator type on patch use, time allocation, and vigilance in gerbils. Oikos 120:1657-1666. DOI: 10.1111/j.1600-0706.2011.19278.x.

Emerson SE., Brown JS., Linden JD. 2011. Identifying Sykes’ monkeys', Cercopithecus albogularis erythrarchus, axes of fear through patch use. Animal Behaviour 81:455-462. DOI: 10.1016/j.anbehav.2010.11.018.

Gaillard J-M., Hebblewhite M., Loison A., Fuller M., Powell R., Basille M., Van Moorter B. 2010. Habitat-performance relationships: finding the right metric at a given spatial scale. Philosophical Transactions of the Royal Society of London. Series B, Biological sciences 365:2255-2265. DOI: 10.1098/rstb.2010.0085.

Gallagher AJ., Creel S., Wilson RP., Cooke SJ. 2017. Energy Landscapes and the Landscape of Fear. Trends in Ecology \& Evolution 32:88-96. DOI: 10.1016/j.tree.2016.10.010.

Gervasi V., Sand H., Zimmermann B., Mattisson J., Linnell JDC., Gervasi V., Sand H., Zimmermann B., Mattisson J., Wabakken P., Linnell JDC. 2013. Decomposing risk : Landscape structure and wolf behavior generate different predation patterns in two sympatric ungulates. Ecological Applications 23:1722-1734. 
954 Gil MA., Zill J., Ponciano JM. 2017. Context dependent landscape of fear : algal density elicits 955 risky herbivory in a coral reef. Ecology 98:534-544. DOI: 10.1002/ecy.1668.

956 Halofsky JS., Ripple WJ. 2008. Fine-scale predation risk on elk after wolf reintroduction in 957 Yellowstone National Park, USA. Oecologia 155:869-877. DOI: 10.1007/s00442-007$958 \quad$ 0956-Z.

959 Hammerschlag N., Broderick AC., Coker JW., Coyne MS., Dodd M., Frick MG., Godfrey MH., 960 Godley BJ., Griffin DB., Hartog K., Murphy SR., Murphy TM., Rose Nelson E., Williams 961 KL., Witt MJ., Hawkes LA. 2015. Evaluating the landscape of fear between apex predatory 962 sharks and mobile sea turtles across a large dynamic seascape. Ecology 96:2117-2126. 963 DOI: $10.1890 / 14-2113.1$.

964 Heithaus MR., Frid A., Wirsing AJ., Dill LM., Fourqurean JW., Burkholder D., Thomson J., 965 Bejder L. 2007. State-dependent risk-taking by green sea turtles mediates top-down effects 966 of tiger shark intimidation in a marine ecosystem. Journal of Animal Ecology 76:837-844. $967 \quad$ DOI: $10.1111 /$ j.1365-2656.2007.01260.x.

968 Hernández L., Laundré JW. 2005. Foraging in the "landscape of fear" and its implications for 969 habitat use and diet quality of elk Cervus elaphus and bison Bison bison. Wildlife Biology 970 11:215-220. DOI: 10.2981/0909-6396(2005)11[215:FITLOF]2.0.CO;2.

971 Iribarren C., Kotler BP. 2012. Foraging patterns of habitat use reveal landscape of fear of Nubian 972 ibex Capra nubiana. Wildlife Biology 18:194-201. DOI: 10.2981/11-041.

973 Jaatinen K., Seltmann MW., Öst M. 2014. Context-dependent stress responses and their 974 connections to fitness in a landscape of fear. Journal of Zoology 294:147-153. DOI: $975 \quad 10.1111 /$ jzo.12169. 
976 Jacob J., Brown JS. 2000. Microhabitat Use, Giving-Up Densities and Temporal Activity as

977 Short- and Long-Term Anti-Predator Behaviors in Common. Oikos 91:131-138.

978 Kauffman MJ., Brodie JF., Jules ES., Url S. 2013. Are wolves saving Yellowstone's aspens? A

979 landscape-level test of a behaviorally mediated trophic cascade. Ecology 91:2742-2755.

980 DOI: $10.1890 / 09-1949.1$.

981 Kauffman MJ., Varley N., Smith DW., Stahler DR., MacNulty DR., Boyce MS. 2007.

982 Landscape heterogeneity shapes predation in a newly restored predator-prey system.

983 Ecology Letters 10:690-700. DOI: 10.1111/j.1461-0248.2007.01059.x.

984 Kuijper DPJ., de Kleine C., Churski M., van Hooft P., Bubnicki J., Jedrzejewska B. 2013.

985 Landscape of fear in Europe: Wolves affect spatial patterns of ungulate browsing in

986 Białowieza Primeval Forest, Poland. Ecography 36:1263-1275. DOI: 10.1111/j.1600-

$987 \quad 0587.2013 .00266 . x$.

988

989

990

991

992

993

994

995

996

Laundré JW. 2010. Behavioral response races, predator — prey shell games, ecology of fear, and patch use of pumas and their ungulate prey. Ecology 91:2995-3007.

Laundré JW., Calderas JMM., Hernández L. 2009. Foraging in the landscape of fear , the predator's dilemma: Where should I hunt? The Open Ecology Journal 2:1-6.

Laundré JW., Hernández L., Altendorf KB. 2001. Wolves, elk, and bison: reestablishing the "landscape of fear" in Yellowstone National Park, U.S.A. Canadian Journal of Zoology 79:1401-1409. DOI: 10.1139/cjz-79-8-1401.

Laundré JW., Hernandez L., Lopez Medina P., Campanella A., Lopez-Portillo J., GonzolezRomero A., Grajales-Tam KM., Burke AM., Gronemeyer P., Browning DM. 2017. The 
997

998

999

1000

1001

1002

1003

1004

1005

1006

1007

1008

1009

1010

1011

1012

1013

1014

1015

1016

1017

landscape of fear : the missing link to understand top-down and bottom-up controls of prey abundance ? Ecology 95:1141-1152. DOI: 10.1890/13-1083.1.

Laundré JW., Hernandez L., Ripple WJ. 2010. The landscape of fear: Ecological implications of being afraid. The Open Ecology Journal 3:1-7. DOI: 10.2174/1874213001003030001.

Lone K., Loe LE., Gobakken T., Linnell JDC., Odden J., Remmen JJ., Mysterud A. 2014. Living and dying in a multi-predator landscape of fear: Roe deer are squeezed by contrasting pattern of predation risk imposed by lynx and humans. Oikos 123:641-651. DOI:

10.1111/j.1600-0706.2013.00938.x.

Lyly MS., Villers A., Koivisto E., Helle P., Ollila T., Korpimaki E. 2015. Avian top predator and the landscape of fear: Responses of mammalian mesopredators to risk imposed by the golden eagle. Ecology and Evolution 5. DOI: 10.1002/ece3.1370.

Madin EMP., Madin JS., Booth DJ. 2011. Landscape of fear visible from space. Scientific Reports 1:1-4. DOI: 10.1038/srep00014.

Makin DF., Payne HFP., Kerley GIH., Shrader AM. 2012. Foraging in a 3-D world: how does predation risk affect space use of vervet monkeys? Journal of Mammalogy 93:422-428. DOI: 10.1644/11-MAMM-A-115.1.

Manning AD., Gordon IJ., Ripple WJ. 2009. Restoring landscapes of fear with wolves in the Scottish Highlands. Biological Conservation 142:2314-2321. DOI: 10.1016/j.biocon.2009.05.007.

Massey J., Cubaynes S., Coulson T. 2013. Will central Wyoming elk stop migrating to Yellowstone, and should we care ? Ecology 94:1271-1274. 
1018 Matassa CM., Trussell GC. 2011. Landscape of fear influences the relative importance of 1019 consumptive and nonconsumptive predator effects. Ecology 92:2258-2266. DOI:

1020 10.1890/11-0424.1.

1021

1022

1023

1024

1025

1026

1027

1028

1029

1030

1031

1032

1033

1034

1035

1036

1037

1038

Mella VSA., Banks PB., Mcarthur C. 2014. Negotiating multiple cues of predation risk in a landscape of fear: What scares free-ranging brushtail possums? Journal of Zoology 294:2230. DOI: 10.1111/jzo.12146.

Nowak K., Le Roux A., Richards SA., Scheijen CPJ., Hill RA. 2014. Human observers impact habituated samango monkeys' perceived landscape of fear. Behavioral Ecology 25:1-6. DOI: $10.1093 /$ beheco/aru110.

Oriol-Cotterill A., Valeix M., Frank LG., Riginos C., Macdonald DW. 2015. Landscapes of Coexistence for terrestrial carnivores: The ecological consequences of being downgraded from ultimate to penultimate predator by humans. Oikos 124:1263-1273. DOI: 10.1111/oik.02224.

Riginos C. 2015. Climate and the landscape of fear in an African savanna. Journal of Animal Ecology 84:124-133. DOI: 10.1111/1365-2656.12262.

Riginos C., Grace JB. 2008. Savanna tree density, herbivores, and the herbaceous community: bottom-up vs. top-down effects. Ecology 89:2228-38.

Ripple WJ., Beschta RL. 2003. Wolf reintroduction, predation risk, and cottonwood recovery in Yellowstone National Park. Forest Ecology and Management 184:299-313. DOI: 10.1016/S0378-1127(03)00154-3.

Ripple WJ., Beschta RL. 2004. Wolves and the Ecology of Fear: Can Predation Risk Structure 
1039

1040

1041

1042

1043

1044

1045

1046

1047

1048

1049

1050

1051

1052

1053

1054

1055

1056

1057

1058

1059

Ecosystems? BioScience 54:755-766. DOI: 10.1641/0006-

3568(2004)054[0755:WATEOF]2.0.CO;2.

Ripple WJ., Beschta RL. 2012. Trophic cascades in Yellowstone: The first 15years after wolf reintroduction. Biological Conservation 145:205-213. DOI: 10.1016/j.biocon.2011.11.005.

Ritchie EG., Johnson CN. 2009. Predator interactions, mesopredator release and biodiversity conservation. Ecology Letters 12:982-998. DOI: 10.1111/j.1461-0248.2009.01347.x.

Rösner S., Mussard-Forster E., Lorenc T., Müller J. 2014. Recreation shapes a "landscape of fear" for a threatened forest bird species in Central Europe. Landscape Ecology 29:55-66. DOI: $10.1007 / \mathrm{s} 10980-013-9964-\mathrm{z}$.

Rypstra AL., Schmidt JM., Reif BD., Devito J., Matthew H., Rypstra AL., Schmidt JM., Reif BD., Devito J., Persons MH. 2007. Tradeoffs Involved in Site Selection and Foraging in a Wolf Spider : Effects of Substrate Structure and Predation Risk. Oikos 116:853-863.

Schmidt K., Kuijper DPJ. 2015. A "death trap" in the landscape of fear. Mammal Research 60:275-284. DOI: 10.1007/s13364-015-0229-x.

Searle KR., Stokes CJ., Gordon IJ. 2008. When foraging and fear meet: Using foraging hierarchies to inform assessments of landscapes of fear. Behavioral Ecology 19:475-482. DOI: 10.1093/beheco/arn004.

Shrader AM., Brown JS., Kerley GIH., Kotler BP. 2008. Do free-ranging domestic goats show "landscapes of fear"? Patch use in response to habitat features and predator cues. Journal of Arid Environments 72:1811-1819. DOI: 10.1016/j.jaridenv.2008.05.004.

Steele MA., Rompré G., Stratford JA., Zhang H., Suchocki M., Marino S. 2015. Scatterhoarding 
1060

1061

1062

1063

1064

1065

1066

1067

1068

1069

1070

1071

1072

1073

1074

1075

1076

1077

1078

1079

1080

rodents favor higher predation risks for cache sites: The potential for predators to influence the seed dispersal process. Integrative Zoology 10:257-266. DOI: 10.1111/17494877.12134.

Sundararaj V., Mclaren BE., Morris DW., Goyal SP. 2012. Can rare positive interactions become common carnivores consume livestock? Ecology 93:272-280.

Suraci JP., Clinchy M., Dill LM., Roberts D., Zanette LY. 2016. Fear of large carnivores causes a trophic cascade. Nature Communications 7:10698. DOI: 10.1038/ncomms10698.

Swanson A., Arnold T., Kosmala M., Packer C. 2016. In the absence of a " landscape of fear ": How lions, hyenas, and cheetahs coexist. Ecology and Evolution 6:8534-8545. DOI: 10.1002/ece3.2569.

Tadesse S. 2012. Habitat quality and foraging ecology of Mountain Nyala (Tragelaphus buxtoni) in the Munessa Forest and the Bale Mountains National Park, South-Eastern Ethiopia.Ph.D. Dissertation. Ben Gurion University of the Negev.

Tadesse S., Kotler BP. 2011. Seasonal Habitat Use by Nuian Ibex (Capra nubiana) evaluated with behavioral indicators. Israel Journal of Ecology and Evolution 57:223-246.

Themb'alilhlwa AMM., Monadjem A., McCleery R., Belmain SR. 2017. Domestic cats and dogs create a landscape of fear for pest rodents around rural homesteads. PloS ONE 1:1-9. DOI: 10.1371/journal.pone.0171593.

Tolon V., Dray S., Loison A., Zeileis a., Fischer C., Baubet E. 2009. Responding to spatial and temporal variations in predation risk: space use of a game species in a changing landscape of fear. Canadian Journal of Zoology 87:1129-1137. DOI: 10.1139/Z09-101. 
1081 Valeix AM., Loveridge AJ., Davidson Z., Murindagomo F., Macdonald DW., Ecology S., Jan

1082 N., Chamaill S., Lyon U De., Mendel BG. 2009. Behavioral Adjustments of African

1083 Herbivores to Predation Risk by Lions : Spatiotemporal Variations Influence Habitat Use.

1084 Ecology 90:23-30.

1085 Van Der Merwe M., Brown JS. 2008. Mapping the landscape of fear of the cape ground squirrel

1086 (Xerus inauris). Journal of Mammalogy 89:1162-1169. DOI: 10.1644/08-MAMM-A-035.1.

1087 Willems EP., Hill RA. 2009. Predator-Specific Landscapes of Fear and Resource Distribution :

1088 Effects on Spatial Range Use. Ecology 90:546-555.

1089 Zanette LY., Sih A. 2015. Gordon Research Conference on Predator-Prey Interactions: from

1090 Genes, to Ecosystems to Human Mental Health. Bulletin of the Ecological Society of

1091 America 96:165-173. DOI: 10.1634/stemcells.2005-0336.

1092 Zanette LY., White AF., Allen MC., Clinchy M. 2011. Perceived predation risk reduces the 1093 number of offspring songbirds produce per year. Science 334:1398-1402. 